\title{
EZH2 in Bladder Cancer, a Promising Therapeutic Target
}

\author{
Mónica Martínez-Fernández ${ }^{1,2, *}$, Carolina Rubio ${ }^{1,2}$, Cristina Segovia ${ }^{1,2}$, \\ Fernando F. López-Calderón ${ }^{1,2}$, Marta Dueñas ${ }^{1,2}$ and Jesús M. Paramio 1,2,* \\ Received: 7 October 2015 ; Accepted: 2 November 2015 ; Published: 13 November 2015 \\ Academic Editor: William Chi-shing Cho \\ 1 Molecular Oncology Unit, CIEMAT (Centro de Investigaciones Energéticas, \\ Medioambientales y Tecnológicas), Avenida Complutense noㅇ. 28040 Madrid, Spain; \\ carolina.rubio@externos.ciemat.es (C.R.); Cristina.Segovia@ciemat.es (C.S.); \\ FernandoFeliciano.Lopez@externos.ciemat.es (F.F.L.-C.); marta.duenas@ciemat.es (M.D.) \\ 2 Biomedical Research Institute I+12, University Hospital “12 de Octubre”, Av Córdoba s/n, \\ 28041 Madrid, Spain \\ * Correspondence: monica.martinez@ciemat.es (M.M.-F.); jesusm.paramio@ciemat.es (J.M.P.); \\ Tel.: +34-91-496-2517 (M.M.-F. \& J.M.P.); Fax: +34-91-346-6484 (M.M.-F. \& J.M.P.)
}

\begin{abstract}
Bladder Cancer (BC) represents a current clinical and social challenge. The recent studies aimed to describe the genomic landscape of $\mathrm{BC}$ have underscored the relevance of epigenetic alterations in the pathogenesis of these tumors. Among the epigenetic alterations, histone modifications occupied a central role not only in cancer, but also in normal organism homeostasis and development. EZH2 (Enhancer of Zeste Homolog 2) belongs to the Polycomb repressive complex 2 as its catalytic subunit, which through the trimethylation of H3 (Histone 3) on K27 (Lysine 27), produces gene silencing. EZH2 is frequently overexpressed in multiple tumor types, including $\mathrm{BC}$, and plays multiple roles besides the well-recognized histone mark generation. In this review, we summarize the present knowledge on the oncogenic roles of EZH2 and its potential use as a therapeutic target, with special emphasis on BC pathogenesis and management.
\end{abstract}

Keywords: bladder cancer; Polycomb; EZH2; miRNA; lncRNA

\section{Introduction}

Bladder cancer (BC) displays one of the highest incidences among different tumors in Western Europe. It also has a high prevalence due to the relatively low mortality. BC incidence is 3 times higher among men than women, being the 4th and the 11th most common cancer, respectively [1]. $\mathrm{BC}$ etiology is quite diverse. It is related with some factors like age, smoking, contact with some chemicals, or even with specific infections [2]. The infection of Schistosoma spp. is estimated to affect about 200 million people in the world. Although its mechanism of action remains unclear, it mostly produces squamous-like carcinomas [3]. It is estimated that $>97 \%$ of all cases occur in endemic areas including Yemen, sub-Saharan Africa, Egypt and Sudan, but some cases have also been reported in Europe probably due to travels to these areas [4-6].

BC is classified depending on the stage (CIS (carcinoma in situ), Ta (Non-invasive papillary carcinoma), T1 (Tumor invades subepithelial connective tissue), T2 (Tumor invades muscularis propria), T3 (Tumor invades perivesical tissue) or T4 (tumor has spread beyond the fatty tissue and nearby organs or structures)), which reveals the location and invasiveness of the tumor. The grade (G1-3) evaluates the differentiation state of the tumor (from highly to poorly differentiated). This classification dates from 1973 and it is the most referenced worldwide [7]. However, there is a more recent classification, published by the World Health Organization (WHO) in 2004 [8]. This new 
classification (TNM) divides the tumors depending on the tumor-stage, on the invasion of the nearby lymph nodes, and on the existence of metastasis [9]. New classifications based on the expression patterns of different cancer-related proteins and genes have been recently proposed [10].

The Non-Muscle Invasive Bladder Cancer (NMIBC) (Ta-T1 stage) is the most frequent form of $\mathrm{BC}$, representing up to $70 \%$ of newly diagnosed cases [11]. The other $30 \%$ represents Muscle Invasive Bladder Cancer (MIBC), from T2 to T4. This characteristic is of extreme relevance as it may define the potential treatment. Patients bearing NMIBC are usually treated by transurethral resection of the bladder tumor (TURBT), which allows bladder preservation and, according specific pathological conditions (size, number of implants, etc.), it is followed by local instillation with chemotherapeutics (mitomycin c, epirubicin, doxorubicin or gemcitabine) $[2,12]$ or Bacillus Calmette-Guérin (BCG). BCG acts as a potential immunomodulator producing a local infection and a consequent inflammatory process, leaded by macrophages, Natural Killer cells, T-cells infiltration, and pro-inflammatory interleukin secretion that contributes to tumor eradication and prevent recurrence $[13,14]$. These adjuvant treatments require several doses for a long period of time, causing an important morbidity. Despite TURBT and chemo/immunotherapy, near $60 \%$ of the patients develop recurrences and, $15 \%$ of them, tumor progression to muscle invasive tumors $[15,16]$. Due to this, $B C$ patients require continuous follow up by cystoscopy, making NMIBC one of the most expensive cancers for the National Health systems of European countries. MIBC treatment implies, in most of the cases, radical cystectomy and conventional chemotherapy with cisplatin, commonly combined with methotrexate, vinblastine and doxorubicin (M-VAC) or carboplatin combined with gemcitabine. The criteria to choose the most suitable treatment are diverse, but it is taken into account the renal function, the heart disease risk, obesity, and other comorbidities [12]. However, metastasis and mortality rates are very high, and survival expectancies are below $10 \%$ by 5 -year in metastatic BC patients $[17,18]$. Remarkably, and in spite of its socioeconomic relevance, no new therapies have been adopted for the treatment of invasive BC for almost 20 years, probably because of a lack of substantial research support in comparison with other tumor types.

Molecular portrait of NMIBC and MIBC has led to the consideration that these two types of tumors arise as a consequence of distinct molecular alterations. In general, NMIBC has been associated with alterations in oncogenes such as PI3KCA (Phosphatidylinositol-4,5-Bisphosphate 3-Kinase, Catalytic Subunit $\alpha$ ) and FGFR3 (Fibroblast growth factor receptor 3) [19-21], whereas MIBC is assumed to proceed through tumor suppressor loss of function, particularly affecting TP53 (Tumor Protein P53) and RB1 (Retinoblastoma 1) genes [22]. These observations have been partially confirmed through the use of next generation massive genomic analysis of tumors [23,24]. Although these studies have been primarily focused in MIBC samples producing some bias of the findings, the results have provided a new landscape of $\mathrm{BC}$ molecular pathology, allowing a novel classification of bladder tumors as intrinsic subtypes, similarly to the concept developed in breast cancer and applied to a number of human malignancies [25]. The proposed intrinsic subtypes by three independent groups [25-27] display high relevance, as they correlate genomic profiles with the clinical outcome, and may represent a new future approach for the management of $\mathrm{BC}$ patients. More recently, the detailed analyses in independent datasets have suggested the molecular convergence to a phenotype that discriminate two major subtypes of BC [28].

In addition, the genomic characterization of $\mathrm{BC}$ samples has allowed the identification of novel pathways. Besides the "usual suspects", BC is also characterized by the frequent alterations in DNA repair and in chromatin remodeling genes [24]. These observations may provide new future therapeutic avenues for the $\mathrm{BC}$ treatment.

Regarding the chromatin-remodeler genes, the involvement of Polycomb Repression Complex (PRC) has gained relevance in the last years, due to its implication in multiple malignancies [29-32]. PRC occurs in two different flavors involved in histone modification: Polycomb Repressor Complex 1 and 2 (PRC1 and PRC2) [33]. PRC2 is mainly composed by four different proteins in mammals: EED (Embryonic Ectoderm Development), SUZ12 (Suppressor of Zeste 12 Homolog), EZH2 and 
RBBP7/4 (Retinoblastoma Binding Protein 7/4). It is implicated in several processes like stemness, maintenance of cell identity, and cell differentiation, [34]. EZH2 is the catalytic subunit of PRC2 and catalyzes the trimethylation of $\mathrm{K} 27$ of $\mathrm{H} 3$ (H3K27me3) [35]. This epigenetic mark primarily generates the repression of gene expression of affected regions in the genome. The overexpression of PRC2 proteins is a common characteristic of various human tumors, including BC, and it is involved in the development and progression of these tumors [36].

The Polycomb Repressor Complex 1 (PRC1) is primarily responsible of the monoubiquitynation of H2AK119 and of chromatin compaction, and recognizes the H3K27me3 mark left by the PRC2 complex. The core is always formed by the RING1A/B protein. It can bind BMI1 (B lymphoma Mo-MLV insertion region 1 homolog), MEL18 (Melanoma Nuclear Protein 18) or NSPC1 (Nervous System Polycomb-1), and associates with CBX (Chromobox homolog) and HPH (Human PolyHomeotic) proteins. It has also been reported that the complex (RING finger protein 1A/B-BMI1) RING1A/B-BMI1 can form other PRC1-like complexes, whose function remains unclear [37]. As in the case of PRC2, increased expression and activity of PRC1 components is also a common hallmark of multiple human cancers [38,39].

\section{EZH2 Biological Function}

The implication of EZH2 in tumorigenesis has been extensively documented in various types of tumors, including breast and prostate. Of note, its roles include not only epigenetic silencing through histone methylation, but also through gene expression activator of different pathways, and as a modulator of other cell proteins (Figure 1).

\subsection{As Epigenetic Silencer}

The EZH2 catalytic activity requires its SET domain [40]. Nonetheless, whole EZH2 activity needs EED and SUZ12, the two other subunits of the PRC2 complex, [41,42], which modulate the efficacy and the substratum preference, allowing the PRC2 allosteric regulation [43].

EZH2 may also cooperate with other epigenetic modifiers, such as DNA methyltransferases (DNMTs) [44] to promote a more permanent silencing of gene expression through CpG island methylation, and with histone deacetylases (HDACs) [45] allowing distinct histone methylation $[33,46]$. In this way, EZH2 acts coordinately with all these elements to silence genes involved in differentiation and cell cycle arrest, favoring stemness maintenance [47].

Interestingly, a novel EZH2 isoform, generated by alternative splicing and named EZH $2 \beta$, has recently been characterized [48]. This isoform shares the gene silencing role with EZH $2 \alpha$, but it differs in its specificity for target genes, as EZH2 $\alpha$ preferentially affects genes involved in cell cycle regulation and cell growth, while EZH $2 \beta$ regulates genes implicated in cell functions such as differentiation, angiogenesis, or stemness maintenance [48]. These differences in the specificity for target genes could be explained because both isoforms differ in a domain, absent in EZH2 $\beta$, subject to various post-transcriptional modifications, including phosphorylation by different protein kinases. The existence of EZH2 isoforms provides a new panorama of the great complexity and plasticity of the remodeling chromatin mechanisms allowing a precise regulation of gene silencing [48].

The capacity of EZH2 to silence tumor suppressor genes or microRNAs justifies its consideration as an oncogenic factor in multiple cancers [49,50]. In this way, EZH2 can activate different oncogenic signaling pathways. For example, EZH2 can activate the non-canonical WNT signaling through the repression of DKK-1 (Dickkopf WNT signaling pathway inhibitor 1), an inhibitor of the WNT co-receptor LRP (Lipoprotein Receptor-related Protein) [51], may mediate the upregulation of RAF1-pERK- $\beta$-CATENIN pathway through RAD51 (DNA Repair Protein RAD51 Homolog 1) [52], inactivate BRCA1 (Breast Cancer gene 1) [53] or RUNX3 (Runt-related transcription factor 3) [54] expression. Finally, it can lead to RAS-ERK-AKT-NF- $\mathrm{kB}$ pathway activation through repression of tumor suppressor DAB2IP (Disabled Homolog 2-Interacting Protein) [55]. 
A
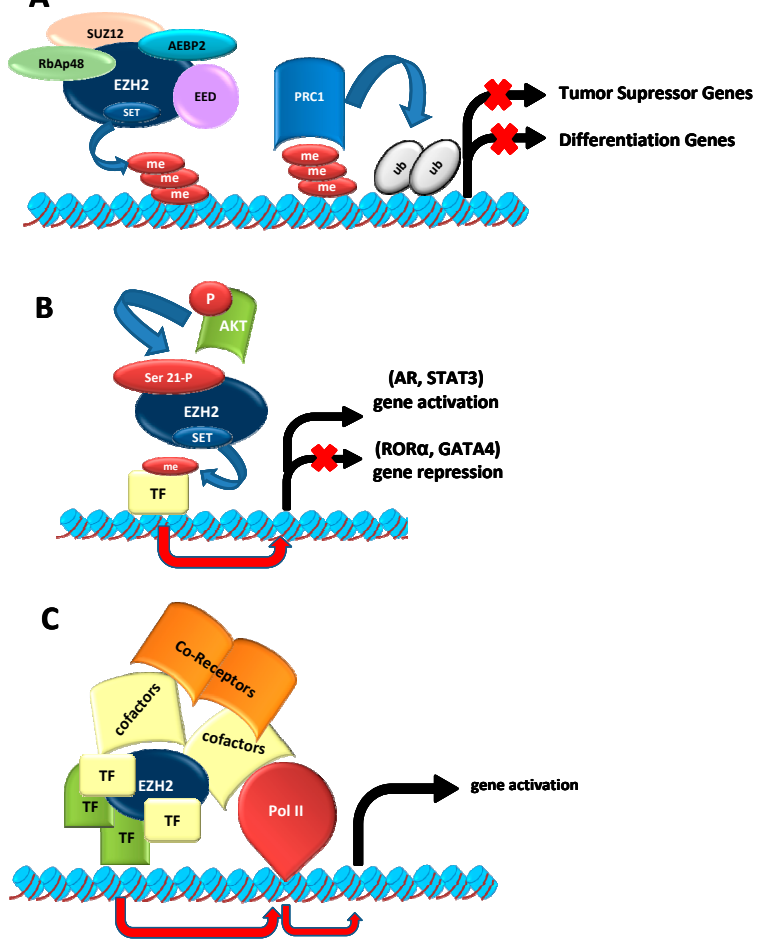

Figure 1. Canonical and non-canonical function of EZH2. (A) EZH2 as epigenetic silencer. EZH2 trimethylates lysine 27, and to a lesser extent, lysine 9 of histone H3 through its SET domain. These marks are recognized by PRC1, which monoubiquitynates lysine K119 on histone H2A, compacts the chromatin, and consequently represses gene transcription. In addition, EZH2 can induce tumor suppressor silencing and tumor progression; (B) PRC2-independent methylation of non-histone proteins. When EZH2 is phosphorylated by AKT in serine 21, it can methylate other proteins such as androgen receptor (AR), or transcription factors like Signal Transducer and Activator of Transcription 3 (STAT3), to activate gene transcription, or it can methylate other factors, such as Retinoid-related Orphan Receptor $\alpha(\operatorname{ROR} \alpha)$ or cardiac factor GATA-binding factor 4 (GATA4), to repress transcription; and (C) Methyltransferase-independent EZH2 functions. EZH2 can act as scaffold protein for various transcriptional factors, such as estrogen receptors (ER) or components of the WNT/ $\beta$-CATENIN signaling pathways to promote gene transcription (see references in the text). EZH2: Enhancer of zeste homolog 2; SUZ12: zing finger protein suppressor os zeste 12; EED: embryonic ectoderm development; SET: conserved domain Su (va) 3-9 Enhancer of Zeste and Trithoax; RbAp48: retinoblastoma-binding protein 48; AEBP2: adipocyte enhancer binding protein 2; AKT: is a serine-threonine specific protein kinase; TF: Transcription Factor. me: methylation; Ub: ubiquitynation; P: phosphorylation; Pol II: RNA polymerase II. The red arrows indicate induction of transcription. The black arrows mean the activation of gene transcription. The black arrow with a red cross means the repression of gene transcription. The light blue cylinders are histones, and the red ribbons are DNA.

\subsection{EZH2 Non-Canonical Roles}

Interestingly, various studies have demonstrated that EZH2 not only acts as epigenetic silencer, but also it can act as a gene activator, independently on PRC2, through methylation of non-histone proteins favoring its oncogenic activity. For instance, in castration-resistant prostate cancer (CRPC), Xu et al. (2012) demonstrated that EZH2 phosphorylation in Serine 21 by AKT can switch its functions from transcriptional repression to gene activation [56]. This modification reduces its affinity for histone $\mathrm{H3}$, allowing the androgen receptor (AR) methylation, or AR-associated proteins, triggering the transcription of specific subset of genes [57]. Similarly, this EZH2 phosphorylation allows the association with STAT3 promoting its methylation and activation in glioblastoma [58]. Remarkably, 
these novel actions may connect two oncogenic pathways, AKT and EZH2, which are supposed to act in an opposite manner regarding gene repression trough histone H3K27 trimethylation [57].

Other oncogenic activities associated with EZH2-mediated methylation of other non-histone proteins independently of PRC2 include the methylation-dependent nuclear receptor ROR $\alpha$ degradation [59]. ROR $\alpha$ has been considered a potential tumor suppressor, and its ubiquitin proteasome-mediated degradation may confer migratory and invasive properties to prostate cancer cells [60], facilitate WNT/ $\beta$-CATENIN signaling in colon cancer [61], and activate proliferation in breast cancer cells [59]. Finally, EZH2 can methylate the transcription factor GATA (Globin Transcription Factor 4); this prevents its interaction with p300 histone acetyltransferase [62]. However, the possible relevance of this interaction in carcinogenesis remains unexplored and, in general, it is not yet known whether the processes of non-histone methylation are particularly restricted to prostate, breast or lymphoma tumors [63] or might be a more general characteristic that contributes to the overall oncogenic activities of EZH2.

EZH2 can also modulate gene expression independently of its histone methyltransferase activity. For instance in breast cancer cells, EZH2 can activate the transcription of different genes in two different manners, depending on the presence or absence of estrogen receptors (ER $\alpha)$. In $\mathrm{ER} \alpha$-positive luminal-like breast cancer cells, EZH2 can form transcription complexes with ER $\alpha$ or its co-activators, facilitating the TCF/ $\beta$-CATENIN-mediated gene transcription [64]. On the other hand, in ER $\alpha$-negative basal-like breast cancer cells, EZH2 can form complexes with RelA and RelB, activating the NF-KB pathway [65]. A similar process, favoring TCF/ $\beta$-CATENIN-transcription, has been described in colon cancer cells, where EZH2 binds PAF transcription complexes [66]. Likewise, EZH2 can induce CYCLIN D1 expression in Natural Killer/T-cell lymphoma cells independently of its methyltransferase activity [67].

The importance of non-canonical function of EZH2 in BC still needs to be clarified. For instance, there are studies showing the STAT3 implication in MIBC [68-70], but its possible relation with EZH2 has not been demonstrated yet. In the case of WNT/ $\beta$-CATENIN pathway, its activation through $\mathrm{EZH} 2$ in $\mathrm{BC}$ cells proliferation has been already described, but the exact activation mechanism is not known [71].

All these processes reinforce the role of EZH2 as an oncogenic factor, in particular associated with aggressiveness, progression and worse clinical outcome [47,72], as well as modulating cell plasticity and favoring intratumoral heterogeneity [73]. However, in spite that many of these signaling pathways are also involved in BC [68-71], the evidences of the involvement of EZH2 independently of its histone methyltransferase in BC are still scarce.

\section{Regulation and Crosstalks}

EZH2 expression can be regulated at multiple levels: it can be transcriptionally induced by multiple factors, such as by E2F family and C-MYC activation [74-76], or by the loss of p53 [77]; it can be also regulated post-transcriptionally through the interaction with microRNAs (miRNAs) and long non coding RNAs (lncRNAs) [78]. Moreover, its levels can be modulated through ubiquitination and degradation by the proteasome system, which are controlled by phosphorylation via PI3K-AKT [57,75] or CDK1 [79]. More recently, it has been demonstrated that EZH2 and SUZ12 can suffer sumoylation, although whether this may also affect their activity remains undetermined [80]. Remarkably, some of these mechanisms may act in various manners. For instance, C-MYC, besides inducing EZH2 transcription [76], can also modulate EZH2 through the induction of PTEN (Phosphatase And Tensin Homolog) expression, which in turn decreases the activity of AKT, thus reducing the inhibitory phosphorylation of EZH2 on Ser21 $[57,75,81]$, and also represses the expression of various miRNAs that target EZH2 [82,83], or induces lncRNAs, such as HOTAIR (HOX transcript antisense RNA) [84], which functionally cooperate with EZH2 to repress gene transcription through H3K27me3 marks [85,86]. 
Regarding the regulation of EZH2 expression and/or activity by non-coding RNAs, special interest has been focused on miRNAs and lncRNAs. The miRNAs are small non-coding transcripts that participates in fundamental biological processes including development, apoptosis, differentiation, and proliferation $[87,88]$. Accordingly, miRNA expression appears deregulated in most, if not all, human cancers. MiRNAs also play important roles in post-transcriptional regulation of enzymes responsible of chromatin modification such as PRC, thus influencing chromatin structure $[89,90]$.

The lncRNAs play a central role both in biological processes and pathological events [91-93]. These include nuclear trafficking (NORN) [94], genomic imprinting (Air, Kcnq1ot1) [95,96], and X-chromosome inactivation (Xist) [97]. Interestingly, both types of RNAs are also interconnected as lncRNAs can act as miRNA decoys, modifying their distribution on their targets [98]. Since lncRNAs have been proven to be in tight association with EZH2 (as we will discuss below in this review), and EZH2 regulates and is regulated by miRNAs, some authors have suggested that EZH2 may play a central role as a mediator in this lncRNA-miRNA-mRNA interaction [78].

\subsection{MiRNAs-EZH2 Interactions}

Several miRNAs have been demonstrated to be involved in EZH2 regulation. In Figure 2, we show a schematic representation of those miRNAs reported to interact with EZH2 in cancer development. Some of them directly regulated EZH2 post-transcriptionally, such as miR-101, miR-26a, miR-214, miR-217, miR-124, miR-138, miR-98, miR-25, miR-30d, miR-199a, miR-29, miR-144 and Let 7 family $[71,83,99-107]$. Among these, miR-101 has been found as negative regulator of EZH2 expression in BC [101,106,108-110]. The miR-101-EZH2 axis stems from previous work in mouse fibroblasts showing that during senescence EZH2 downregulation together with the histone demethylase KDM2B induces the expression of miR-101 [111]. In this system, the enforced expression of KDM2B caused the demethylation of $\mathrm{H} 3 \mathrm{~K} 36$ repressing the expression of miRNAs let-7b and miR-101, which in turn increased the EZH2 expression, contributing to cell immortalization. In BC cells, a similar axis involving NDY1/KDM2B-miR-101-EZH2 has been identified [112].

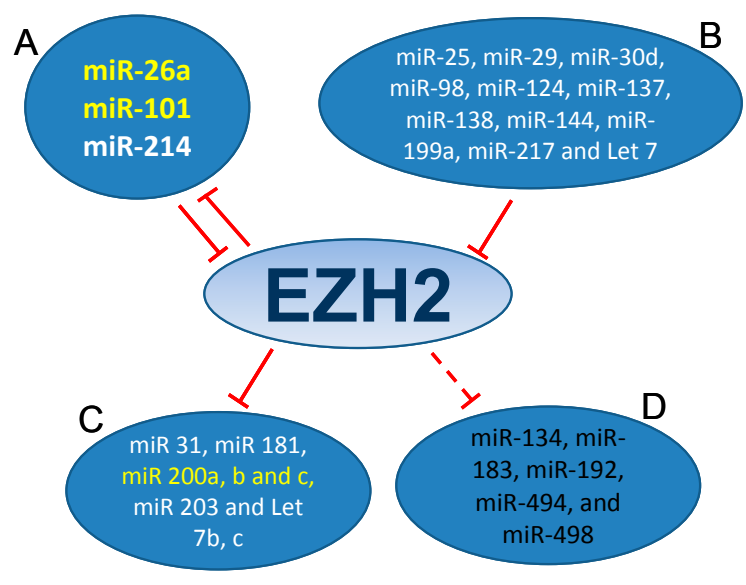

Figure 2. EZH2-miRNA network. The circles (A,B) show the miRNAs that regulate EZH2 by interacting with its $3^{\prime}$ UTR. Circle (A) includes those miRNAs that, besides regulating EZH2, are also regulated/silenced by EZH2. The circles $(\mathbf{C}, \mathbf{D})$ indicate those miRNAs whose expressions are suppressed by EZH2 (C) or whose expression are silenced by hypermethylation (D). In white, the miRNAs with experimental evidence of EZH2 interaction; those that are also observed in BC are denoted in yellow; and in black those miRNAs without direct evidence of expression repressed by EZH2.

EZH2 is not only regulated by, but it also regulates a wide variety of miRNAs through epigenetic repression. These miRNAs may act as tumor suppressors, modulating tumor growth, a 
cancer stem cell phenotype, and cancer cell invasiveness. This EZH2-mediated repression has been demonstrated for miR-31, miR-200a-b-c, miR-181, miR-203, and Let 7b-c [50,111,113,114]. Among them, miR-181a-b, miR-200a-b-c and miR-203 are regulated by EZH2 and inhibit the expression of BMI1 and RING2, both PRC1 members. These findings suggest a possible regulatory axis including miRNAs-EZH2-miRNAs-PRC1 in advanced cancer [115]. The situation of miR-200 family members in this axis is of particular relevance in the context of BC. Liu et al. (2014) [116] reported that enforced expression of miR-200c in BC cell lines drastically reduced transcription factor E2F3, which acts as a positive activator of EZH2 and BMI1 transcription [74,117]. Interestingly, the two miR-200 clusters are concurrently silenced by promoter hypermethylation in advanced BC [118,119]. In addition, increased EZH2, which is a common hallmark of NMIBC at high risk of recurrence and tumor progression in recurrences [117], also caused a decrease of miR-200 family expression, and the knock down of EZH2 or its inhibition, using DZNep (3-Deazaneplanocin A), resulted in an increased expression of the miR-200 family in BC cell lines [108]. A similar effect of BMI1 suppressing miR-200 expression has been reported in other tumor types, such as breast and prostate [50] and in BC [119].

Of note, among the miRNAs that regulate EZH2, miR-26a, miR-101 and miR-214 have been proven to be repressed by EZH2. Varambally et al. (2008) [99] reported that the decreased expression of miR-101 correlated with high level of expression of EZH2 and H3K27me3 during prostate cancer progression. Last year, Wang et al. (2014) [82] described a feedback loop connecting EZH2, C-MYC and miR-101 leading to miRNA silencing in hepatocarcinogenesis. The molecular mechanism of this circuitry has been unveiled in B cell lymphomas [120]. In this system, EZH2 is recruited by C-MYC, epigenetically repressing the expression of miR-101. This downregulation of miR-101 expression increased expression of EZH2 and EED [120]. Similar circuitry has been demonstrated for miR-26a in Burkitt lymphoma cell lines supporting also the existence of an axis of MYC-miR-26a-EZH2-target genes in those lymphomas associated with MYC activation [83]. In the case of the miR-214 the regulatory feedback loop is direct. Juan et al. (2009) [100] reported that during skeletal muscle differentiation the miR-214 locus is activated by disengagement of PRC2 resulting in its transcription and when transcribed, miR-214 binds the $3^{\prime} \mathrm{UTR}$ region of EZH2 decreasing the EZH2 protein level.

Some miRNAs frequently associated to EZH2 regulation in several tumor types, such as bladder and gastric cancer, hepatocellular carcinoma and neuronal differentiation, include miR-214, miR-124 and miR-137 [120-123]. However, although these miRNAs are frequently downregulated in BC associated with increased stage and grade, no direct association has been conclusively reported between these miRNAs and EZH2 in bladder carcinogenesis [124,125]. Nonetheless, as EZH2 can also modulate DNA methylation (see below), it would be interesting to monitor the existence of direct correlation between EZH2 expression and the expression of these and other miRNAs reported to be epigenetically silenced by methylation in BC, such as miR-498, miR-494, miR-192, miR-183, and miR-134 [126].

\subsection{LncRNAs-EZH2 Interactions}

Long non-coding RNAs (lncRNAs) functions include to induce local gene silencing through binding to chromatin modification complexes, to recruit chromatin modifiers, and to act as scaffolds for chromatin modifying factors changing histone marks thereby modifying gene expression [78,127]. Their right functioning is fundamental for normal tissue maintenance, being their aberrant expression described in different human cancers $[93,128,129]$.

Several lncRNAs have been shown to interact with PRC2, facilitating its recruitment to the promoter of some target genes. For instance, the Prostate Cancer Associated ncRNA Transcript-1 (PCAT-1) is markedly increased in high-grade and metastatic prostate cancer. Its demonstrated interplay with PRC2 suggests that it could have an important role in prostate cancer progression [115].

Another example is the IncRNA H19. Luo et al. (2013) [130] demonstrated that IncRNA H19, already described as an enhancer of tumorigenic potential of carcinoma cells in vivo, promoted BC metastasis inhibiting E-CADHERIN expression and by associating with EZH2 . 
The IncRNA Up-regulated in Bladder Cancer 1 (linc-UBC1) also can be physically associated with PRC2 complex and appeared frequently upregulated in BC. It promotes increased cell proliferation, migration, invasion, metastatic potential, and its increased expression correlates with poor clinical outcome [131].

The IncRNA Antisense Non-coding RNA in the INK4 (INhibitors of CDK4) Locus (ANRIL) has been located within the p15/CDKN2B (Cyclin-dependent kinase inhibitor 2B)-p16/CDKN2A (Cyclin-dependent kinase inhibitor 2A)-p14/ARF (ADP Ribosylation Factor) gene cluster. It interacts with EZH2, SUZ12, and the PRC1 subunit CBX7 (ADP Ribosylation Factors) mediating the silencing of $p 16 I N K 4 a, p 15 I N K 4 b$ and $p 14 A R F$ tumor suppressors through the recruitment of PRC2 and PRC1 [132-134]. In prostate cancer compared to normal prostate, its expression is increased and correlated with increased EZH2 occupancy levels near the INK4a and ARF genes promoters [132]. However no differences have been recently observed in both NMIBC and MIBC, indicating a poor involvement in the development of this tumor type [24,135].

The most documented example of EZH2-lncRNA functional interaction is the Homeobox Antisense Intergenic RNA (HOTAIR). It is transcribed in antisense direction from the HOXC (Homeobox C) gene cluster and binds to $E Z H 2$ recruiting PRC2 complex to specific target genes genome-wide. Kaneko et al. (2010) [85] and Tsai et al. (2010) [86] demonstrated that EZH2 interacts with HOTAIR to regulate gene expression. HOTAIR is frequently up-regulated in different cancer tissues, in particular in aggressive forms, and associated with metastasis development and poor clinical outcome [136-139]. Similarly, HOTAIR expression has also a prognostic value for BC recurrence, progression, and patient survival $[135,140]$. However, the functional roles of HOTAIR in modulating the cancer epigenome have not been completely elucidated. For example, in HOTAIR-deficient mice, the absence of this IncRNA causes H3K4me3 gain, whereas the effect on H3K27me3 is less evident [105]. Since HOTAIR also interacts with the LSD1 (Lysine-Specific Demethylase 1) H3K4-specific demethylase, these findings may hamper the potential relevance of the HOTAIR-EZH2 interaction in vivo. Whether these effects observed during normal mouse development could also similarly affect carcinogenesis, or if there are species-specific differences attributable to the disparity between mouse and human HOTAIR [141], remains to be elucidated.

\subsection{EZH2 Interaction with Other Epigenetic Enzymes}

Although PRC2 functions predominantly repressing target genes via the H3K27me3 repressive mark, other epigenetic mechanisms seem to be also involved in this gene silencing mediated by EZH2. Indeed, PRC2 components interact with DNMTs (DNA methyltransferases) and HDACs [142]. The DNMTs expression (DNMT1, DNMT3A, and DNMT3B) leads to gene inactivation by catalyzing the methylation of cytosine at $\mathrm{CpG}$ sites in the regulatory sites of target genes. EZH2 can bind and recruit DNMT1, DNMT3A and DNMT3B to their targets [44]. Moreover, EZH2 is required for binding of DNMTs and facilitates CPG methylation of EZH2-target promoters [44]. This process adds complexity and plasticity to the epigenetic program in which methylation of histones and DNA cooperates in an integrating gene-silencing network within the cell. In the cancer context, this interaction has been less explored. Indeed, the possibility that to reprogram the cancer epigenome both mechanisms can act in parallel has been already postulated [143]. Accordingly, the polycomb repressive mark and DNA methylation can act separately in subset of genes, whereas in other genes there is an "epigenetic switching" from a plastic polycomb mark to the more stable silencing by DNA methylation [143]. As a consequence, this switch does not lead to de novo repression but might significantly cause a reduction in the epigenetic plasticity, leading to a permanent repression of key regulatory genes and contributing to tumor development and/or progression.

In this regard, the concerted action of DNMT1 and EZH2 mediates the repression of the miR-200a,b/429 locus contributing to the progression of gastric cancer and glioblastoma [144]. Interestingly, we have also recently reported that these miRNAs display reduced expression during BC progression by promoter methylation and/or EZH2 expression [119], suggesting that 
this repression could be mediated by EZH2-DNMTs collaborative activity. This represents an attractive possibility for future analyses, as they might also provide new therapeutic strategies for $\mathrm{BC}$ management.

Besides the H3K27me3, other well-characterized histone methylation event is the H3K9me2/3, a hallmark of constitutive heterochromatin. This methylation is catalyzed by specific histone methyltransferases (HMTs), including G9a (EHMT2), GLP (EHMT1) and SUV39H (Suppressor of Variegation 3-9 Homolog). Interestingly, although H3K9me2/3 and H3K27me2/3 marks were first thought to have distinct functions and to be mutually exclusive in genome, recent studies show the co-occupancy of these repressive marks at several gene loci $[145,146]$, and a cooperative mechanisms for both methylation marks in keeping gene silencing in part through the recruitment of other protein partners [147,148]. More interestingly, the physical interaction between PRC2 core components and G9a/GLP has been recently described [149] allowing G9a/GLP to control the PRC2 recruitment and H3K27me3-mediated silencing at specific genomic loci [149]. The deregulated expression of G9a/GLP complexes in many tumors including hepatocellular, colon, prostate, lung, bladder, and in B cell chronic lymphocytic leukemia [150] possess a new possible mechanism contributing to PRC2 roles in tumorigenesis. This hypothesis still remains to be confirmed.

On histone tails, lysine residues can also undergo acetylation, resulting in a more open chromatin configuration [151]. Histone acetyl transferases (HATs) and deacetylases (HDACs) catalyze the dynamic regulation of acetylation. They add or remove, respectively, acetyl groups from histone tails. The deregulated expression of the various HDACs has been described in different cancer types, including urothelial tumors [152]. However, the variations in the expression of these isotypes, being some of them upregulated whereas others are repressed, makes difficult the use of general inhibitors, such as vorinostat, in the management of BC $[153,154]$. PRC2 could recruit HDACs through EED leading to cooperative repression of gene expression $[155,156]$. In addition, HDACs could deacetylate H3K27, allowing the subsequent methylation by PRC2, or could also deacetylate other histone lysines to adjust the local histone code for silencing, in a process similar to that described for Nucleosome Remodeling Deacetylase (NuRD) [42].

On the other hand, lysine-specific demethylases (KDMs) counteract different histone methyltransferases including EZH2 [111,157]. Several human isoforms KDMs have been already described [158,159]. The JmjC (Jumonji C) domain-containing proteins, UTX/KDM6A (Lysine (K)-Specific Demethylase 6A) and JMJD3/KDM6B (Lysine (K)-Specific Demethylase 6B), can particularly remove di- and trimethyl marks from H3K27 and acting against the histone modification mediated by EZH2 [160-163]. KDM6A was the first described mutated histone demethylase gene in human cancer [164], and most mutations cause loss of function [165]. Importantly KDM6A is among the most frequently mutated genes in $B C[166,167]$ and its frequent loss of function also reinforces the oncogenic roles of EZH2 in these BC tumors, as the EZH2 activity (as histone methyltransferase) is opposed by that of KDM6A. In contrast to KDM6A, and in spite of having similar enzymatic function, no significant mutations or changes in expression have been reported for JMJD3/KDM6B in BC. In this regard, opposite functions of KDM6B and KDM6A have been demonstrated in the T-cell acute lymphoblastic leukaemia (T-ALL) [168], being KDM6B essential to initiate and maintain these tumors, whereas KDM6A acts as a tumour suppressor, being frequently genetically inactivated. The possibility that similar opposite functions also happen in BC needs further detailed studies.

\section{Pharmacological Treatment}

As described above, EZH2 represents an oncogenic signal in several types of cancer, as prostate, liver, breast, colon, skin, lymphoma, endometrial, lung, myeloma, gastric, and BC $[42,169,170]$. Therefore, its inhibition may be a key approach for cancer treatment. This fact has inspired various pharmaceutical companies and academic research groups to develop inhibitors of EZH2 (Table 1 and Figure 3). Such inhibition of EZH2 could be achieved through direct inhibitors or through indirect mechanisms. 
Table 1. Inhibitors developed against EZH2.

\begin{tabular}{|c|c|c|c|c|c|}
\hline Name & Structure & Mechanism & Specificity to EZH2 & Clinical Status & References \\
\hline DZNEP & & $\begin{array}{l}\text { SAH Hydrolase } \\
\text { Inhibitor }\end{array}$ & No & Preclinical & [171-173] \\
\hline D9 & & $\begin{array}{l}\text { SAH Hydrolase } \\
\text { Inhibitor }\end{array}$ & No & Preclinical & [174] \\
\hline EPZ005687 & & $\begin{array}{l}\text { SAM-Competitive } \\
\text { Inhibitor }\end{array}$ & Yes & Preclinical & [175] \\
\hline EPZ-6438 & & $\begin{array}{l}\text { SAM-Competitive } \\
\text { Inhibitor }\end{array}$ & Yes & Phase I/II trial & [176] \\
\hline EPZ0011989 & & $\begin{array}{l}\text { SAM-Competitive } \\
\text { Inhibitor }\end{array}$ & Yes & Preclinical & [177] \\
\hline EI1 & & $\begin{array}{l}\text { SAM-Competitive } \\
\text { Inhibitor }\end{array}$ & Yes & Preclinical & [178] \\
\hline GSK126 & & $\begin{array}{l}\text { SAM-Competitive } \\
\text { Inhibitor }\end{array}$ & Yes & Phase I trial & [179] \\
\hline GSK343 & & $\begin{array}{l}\text { SAM-Competitive } \\
\text { Inhibitor }\end{array}$ & Yes & Preclinical & {$[180,181]$} \\
\hline UNC1999 & & $\begin{array}{l}\text { SAM-Competitive } \\
\text { Inhibitor }\end{array}$ & $\begin{array}{l}\text { Specificity } \\
\text { to EZH1/2 }\end{array}$ & Preclinical & {$[182,183]$} \\
\hline CPI-360 & & $\begin{array}{l}\text { SAM-Competitive } \\
\text { Inhibitor }\end{array}$ & Yes & Preclinical & [184] \\
\hline
\end{tabular}


Table 1. Cont.

\begin{tabular}{|c|c|c|c|c|c|}
\hline Name & Structure & Mechanism & Specificity to EZH2 & Clinical Status & References \\
\hline CPI-169 & & $\begin{array}{l}\text { SAM-Competitive } \\
\text { Inhibitor }\end{array}$ & Yes & Preclinical & [184] \\
\hline $\begin{array}{l}\text { SAH-EZH2 } \\
\text { Peptide }\end{array}$ & $\begin{array}{c}\text { Peptide: } \\
\text { FSSNRXKILXRTQI } \\
\text { LNQEWKQRRIQPV }\end{array}$ & $\begin{array}{l}\text { Disrupts the } \\
\text { EZH2-EED complex }\end{array}$ & Yes & Preclinical & [185] \\
\hline NSC745885 & & $\begin{array}{c}\text { Degradation of EZH2 } \\
\text { by proteasome }\end{array}$ & Yes & Preclinical & [186] \\
\hline GA and MJ & Methyl J & $\begin{array}{l}\text { Down-regulation of } \\
\text { EZH2 expression by } \\
\text { mir-101 up-regulation }\end{array}$ & Yes & Preclinical & [187] \\
\hline
\end{tabular}

SAH: S-adenosyl-L-Homocysteine; SAM: S-adenosyl-L-methionine; SAH-EZH2: Stabilized- $\alpha$-helix of EZH2.

\subsection{S-Adenosyl-L-homocysteine Hydrolase (SAH Hydrolase) Inhibitors}

The EZH2 protein contains different domains: $\mathrm{H} 1$ and $\mathrm{H} 2$ domains conform the binding region for PHF1 and SUZ12 respectively; cysteine rich domain, SANT domain to interact with histones; and C-terminal SET domain [63]. The catalytic activity of EZH2 resides in the SET domain [170]. It catalyzes the methyl group transfer from a universal methyl donor, S-adenosyl-L-methionine (SAM), to the lysine side chains of the acceptor protein. This generates S-adenosyl-L-homocysteine (SAH), which is further processed by the S-adenosyl-L-homocysteine hydrolase (SAH Hydrolase) [188].

One of the best characterized EZH2 inhibitors is 3-dezaneplanocin-A (DZNep), an equivalent of 3-deazaadenosine. It blocks the activity of SAH Hydrolase [170,189], producing the accumulation of SAH in cells and thus overall reduction of SAM, causing the indirect inhibition of the EZH2 methyltransferase activity. In addition, DZNep also causes the degradation of EZH2 probably through the ubiquitin-proteosome system [171,190]. These observations might support the widely reported preclinical antitumoral activities of this compound [172,173,191-194]. Although there is no data about how to predict its response in BC, it has been recently described TP53 genomic status influences DZNep response in gastric cancer [193]. However, current studies indicate that DZNep act as a global inhibitor of histone methylation, and probably inhibits diverse methyltransferases, in agreement with its pharmacologic impairment of SAH Hydrolase activity and the overall reduction of SAM [172]. Therefore, DZNep fails to be a specific and selective EZH2 antagonist [189,195].

This lack of specificity has led to the development of DZNep analogs with improved characteristics. One of them, named compound D9 has shown effectiveness in acute myeloid leukemia cells through the inhibition of various oncogenic signaling pathways [174]. Moreover, D9 can deplete the leukemia stem cells (LSC) and abolish chemotherapy-induced LSC enrichment, producing dramatic elimination of acute myeloid leukemia (AML) cell survival [174]. Therefore, in spite of the undetermined precise mechanism of action and the lack of in vivo data, D9 is becoming an interesting drug candidate thanks to its anti-cancer effects. 


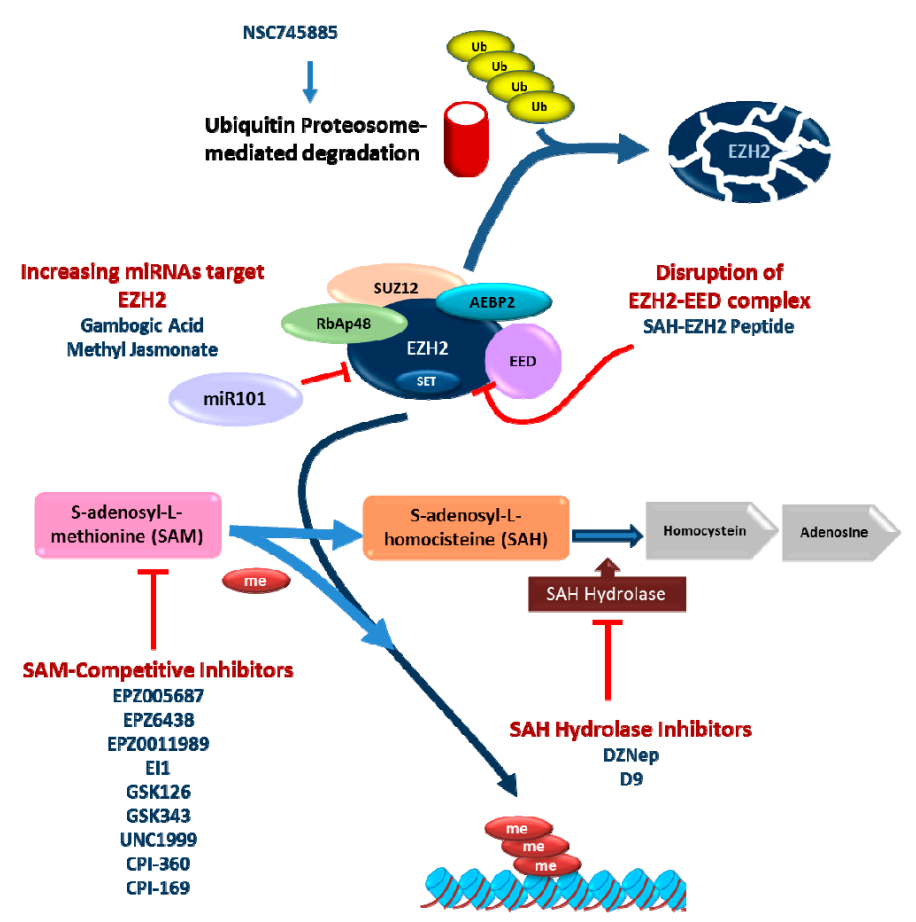

Figure 3. Inhibitors developed against EZH2. The five types of inhibitors are indicated: "Sadenosyl-L-homocysteine hydrolase inhibitors", "S-adenosyl-L-methionine competitive inhibitors", "S-adenosyl-L-homocysteine-EZH2 peptides as disruptors of the contact between EZH2 and EED", "Degradation by ubiquitin proteasome pathway", and "Downregulation mediated by the increased expression of miRNAs target of EZH2". EZH2: Enhancer of zeste homolog 2. SUZ12: Zinc finger protein suppressor of zeste 12. EED:WD40 Repeat protein embryonic ectoderm development. SET: Su(var)3-9E Enhancer of zeste and Trithorax RbAp48: Retinoblastoma-binding protein p48. AEBP2: Adipocyte Enhancer-Binding Protein 2. DZNep: 3-dezaneplanocin-A Me: methylation. Ub: ubiquitination Mir101: miRNA-101. Arrow blue: activation of different pathways Arrow red: inhibition of different molecules. Light blue cylinders are histones, and with red ribbons are DNA.

\subsection{S-Adenosyl-L-methionine (SAM) Competitive Inhibitors of EZH2}

Various inhibitors have been developed to achieve the competitive inhibition of the SAM binding to the SET domain of EZH2 [188]. These include EPZ-005687, EPZ-6438 (also named E-7438), developed by the pharmaceutics Epizyme [176]. Although both compounds are similar in their mechanism, EPZ-6438 has better properties regarding oral bioavailability in animals [176]. They preferentially inhibit the activity of EZH2 mutants (residues Y646, A682, and A692) found in B cell non-Hodgkin lymphoma [176]. In fact, EPZ-6438 is presently under study in a Phase I/II trial in solid tumors or B-cell lymphoma (Clintrial.gov identifier: NCT01897571) [176]. Recently Campbell et al. (2015) have published other molecule, EPZ-011989, whose difference with EPZ-6438 is a replacement of the second benzene ring and pyridine residue to increase the range of EZH2 inhibition, improving the pharmacokinetics and pharmacodynamics qualities, at least in a mouse xenograft model of human B cell lymphoma [177].

Other SAM-competitive inhibitors are EI1 from Novartis [178], and GSK126 from GlaxoSmithKline [179]. These two inhibitors caused loss of global genome H3K27 methylation, and reactivation of PRC2-silenced genes. Both act at low concentrations as antitumoral agents in diffuse large B-cell lymphoma cells (DLBCL), particularly when bearing EZH2 activating mutations. GSK126 has also been tested in mouse DLBCL xenograft [179]. GSK126 is currently under study Phase I clinical trial in adult patients of follicular lymphoma and relapsed diffuse large B cell lymphona (Clintrial.gov 
identifier: NCT02082977). Another derivative, GSK343 has shown preclinical antitumoral activity in three-dimensional culture of epithelial ovarian cancer [181].

A dual inhibitor of EZH2 and EZH1 (UNC1999) has also been developed [183]. It is structurally equivalent of GSK343, and is effective in DLBCL cells. Importantly, its EZH2/1 dual activity has a potential benefit in Mixed Lineage Leukemia (MLL) cancer cells [182].

Constellation Pharmaceuticals have developed various compounds with potential EZH2 inhibitory activity. After a general screening in search for potential inhibitors inducing genome-wide histone H3K27me3 reduction with activity at nanomolar concentration, they identified the lead compound CPI360 [196]. CPI-360 also acts through SAM-competition, reducing global H3K27me3 and H3K27me2 levels depending on the dose, but not affecting the protein levels of PRC2 subunits or the global levels of other tri- and dimethylation marks [184]. It has demonstrated activity against Y641N mutant EZH2-containing Germinal Center B Cell-like Diffuse Large B Cell Lymphoma cells (GCB-DLBCL) [184]. Unfortunately, complete target coverage could not be completed due to inadequate pharmacological properties [184]. Afterwards, CPI-169, a more potent EZH2 inhibitor, was identified with improved stability. CPI-169 showed effectiveness also in wt-EZH2 on GCB-DLBCL cells [197].

\subsection{Other Approaches}

The ability of SAH to inhibit the catalytic activity of EZH2 has been exploited by various groups trying to avoid the general effects attributable to overall SAH accumulation. One of them consists on the generation of stabilized peptides mimicking the $\alpha$-helix of EZH2. This domain recognizes the corresponding domain of EED, therefore promoting the dissociation of the EZH2/EED complex, and impairing the function of PRC2 [185]. Detailed studies in comparison with GSK126 demonstrated a potential different mechanism, which caused growth arrest and induced differentiation of MLL-AF9 leukemia cells [185]. Nonetheless, a major caveat of this approach is the utility of these stabilized peptides in vivo. Indeed, while they are easily internalized by the cells in vitro, an in vivo investigation is still needed. In addition, as mentioned above, some EZH2 functions are independent on the binding to other PRC2 components. Consistently, these peptidomimetics approach will not impair these activities.

A series of compounds, also based on the structure of $\mathrm{SAH}$, have been recently developed by Pfizer researchers [198]. Importantly, some of these newly characterized compounds displayed improved selectivity against EZH2 compared with the inhibition produced by SAH, without significant effects on other methyltransferases [198].

As mentioned above, EZH2 is also regulated by proteasome-mediated proteolysis $[57,75,78,79,199]$. Consequently, a possible approach to inhibit PRC2 activity is to increase this EZH2 degradation. Emodin (6-methyl-1,3,8-trihydroxyanthraquinone) is a natural product derivative that possesses multiple anti-cancer effects [200], and downregulates EZH2-mediated H3K27 trimethylation in BC cells [201]. Subsequently, novel Emodin derivatives have been obtained. Among them, NSC745885 have shown to cause EZH2 downregulation by increased proteasome-mediated degradation in BC cells, but not in immortalized non-tumorigenic bladder cells, and to suppress tumor development in vivo [186]. Nonetheless, considering the wide use of proteasome inhibitors as antitumoral agents, the observed finding of NSC745885 mediating increased proteasome degradation of EZH2, would require extensive studies to avoid possible side off effects.

Finally, another potential approach is to induce the expression of miRNAs targeting EZH2. Such approach has been reported for the natural product derivatives Gambogic Acid (GA) and Methyl Jasmonate (MJ). They are both considered promising therapeutic agents against various cancer types including prostate, pancreas, gastric, breast, and lung cancer, and their combination causes synergistic inhibitory activity. Interestingly, in a recent detailed study focused on BC cells, it has been shown that MJ significantly sensitized BC cells to GA-induced growth inhibition and apoptosis [187]. The plausible mechanism of this effect was attributed to EZH2 downregulation mediated by the increased 
expression of miR-101. Although a detailed molecular basis of such increased expression of miR-101 is still missing, the GA plus MJ combination exerted remarkable antitumor inhibitory activities in xenograft mouse models of human BC [187], thus demanding possible extensive studies on this combination for the possible future management of $B C$.

The role of EZH2 in chemotherapy resistance is to be determined in BC, although recent studies showed that acquired cisplatin resistance in ovarian cancer appeared linked to overexpression of EZH2 [202,203], in clear cell renal cell carcinoma models [204] or in lung adenocarcinoma [205]. In addition, increased EZH2 expression has been demonstrated to appear associated with worse outcome to tamoxifen therapy in metastatic breast cancer [206]. Intervention of EZH2 also inhibited the growth of Temozolomide-resistant glioblastoma cells [207].

\section{Concluding Remarks}

EZH2 plays a main role on the maintenance of cellular epigenetic integrity, being highly relevant on human BC, among other tumors such as prostate, breast, ovarian, renal carcinoma, lung, liver, brain, gastric, esophageal, pancreatic, or melanoma. As a main player within cancer epigenetics, it can become a promising tool for detection, diagnosis, prognosis, and prediction of response to possible therapies. Nevertheless, and in spite of the wide knowledge on EZH2 in normal development and in pathological conditions, there are still a large number of unanswered questions, which might be particularly relevant in BC and other cancers, where EZH2 upregulation appears to dictate the malignant progression. For instance, it is mandatory the identification of EZH2 target genes that are directly responsible for such oncogenic progression. In addition, it is interesting to determine whether EZH2 functions independent on histone methyltransferase are of relevance in these tumors. Similarly, whether the inactivation of KDM6A is equivalent to EZH2 overexpression is still unknown. There is still paucity in studies of EZH2 inhibitors in solid tumors, including BC. In these studies, the reported differences between long term EZH2 depletion as antitumoral approach in vivo using genetic technologies [208] or short-term EZH2 inhibition, such as that obtained with pharmacological approaches, should be deeply considered, to avoid reactivation and progression of the tumors [208]. Another aspect still obscure is the possible use of other inhibitors that may account of a partial EZH2 inhibition. As mentioned, the interaction of EZH2 with DNMTs or EHMT may account for some of the oncological properties of EZH2, and whether the inhibition of these partners also results in reduction of overall EZH2 activity is still unknown.

In summary, although our knowledge on the molecular mechanisms of EZH2 in relation with malignant transformation has been greatly improved in the recent years, there is still a lot of missing information necessary for full establishment of clinical settings of using this molecule as a target for cancer patients, in particular in BC.

Acknowledgments: This study was funded by the following: MINECO (Ministry of Economy and Competitiveness grant) SAF2012-34378; Comunidad Autónoma de Madrid grant S2010/BMD-2470 (Oncocycle Program); AES (Acción Estratégica en Salud) grant ISCIII-RETIC RD12/0036/0009 to Jesús M. Paramio and grant AP99782012 from MMA (Mútua Madrileña) Foundation to Marta Dueñas. The work carried out at Jesús M. Paramio laboratory receives support from the European Community through the regional development funding program (FEDER).

Author Contributions: All authors contributed equally to review the current literature and write specific sections. The whole work was coordinated by Mónica Martínez-Fernández and Jesús M. Paramio, who also wrote the final version. All the authors agreed with the final version.

Conflicts of Interest: The authors declare no conflict of interest.

\section{References}

1. Ploeg, M.; Aben, K.K.H.; Kiemeney, L.A. The present and future burden of urinary bladder cancer in the world. World J. Urol. 2009, 27, 289-293. [CrossRef] [PubMed] 
2. Burger, M.; Catto, J.W.F.; Dalbagni, G.; Grossman, H.B.; Herr, H.; Karakiewicz, P.; Kassouf, W.; Kiemeney, L.A.; la Vecchia, C.; Shariat, S.; et al. Epidemiology and risk factors of urothelial bladder cancer. Eur. Urol. 2013, 63, 234-241. [CrossRef] [PubMed]

3. Abol-Enein, H. Infection: Is it a cause of bladder cancer? Scand. J. Urol. Nephrol. Suppl. 2008, 42, 79-84. [CrossRef] [PubMed]

4. Blach, O.; Rai, B.; Oates, K.; Franklin, G.; Bramwell, S. An outbreak of schistosomiasis in travellers returning from endemic areas: The importance of rigorous tracing in peer groups exposed to risk of infection. J. Public Health 2012, 34, 32-36. [CrossRef] [PubMed]

5. Douard, A.; Cornelis, F.; Malvy, D. Urinary schistosomiasis in France. Int. J. Infect. Dis. 2011, 15, e506-e507. [CrossRef] [PubMed]

6. Oyaert, M.; Lagrange, W.; Smet, G.; de Feyter, K.; Laffut, W. Unexpected urinary Schistosoma infection in a Belgian travel group returning from Malawi. Acta Clin. Belg. 2013, 68, 234-236. [CrossRef] [PubMed]

7. Mostofi, F.K.; Sobin LH, T.H. Histological Typing of Urinary Bladder Tumours; World Health Organisation: Geva, Switzerland, 1973.

8. Eble, J.N.; Sauter, G.; Epstein, J.I.; Sesterhenn, I.A.E. Pathology and Genetics of Tumours of the Urinary System and Male Genital Organs; IARC Press: Lyon, France, 2004.

9. Lopez-Beltran, A.; Luque, R.J.; Alvarez-Kindelan, J.; Quintero, A.; Merlo, F.; Requena, M.J.; Montironi, R. Prognostic factors in survival of patients with stage Ta and T1 bladder urothelial tumors: The role of G1-S modulators (p53, p21Waf1, p27Kip1, cyclin D1, and cyclin D3), proliferation index, and clinicopathologic parameters. Am. J. Clin. Pathol. 2004, 122, 444-452. [CrossRef] [PubMed]

10. Knowles, M.A.; Hurst, C.D. Molecular biology of bladder cancer: New insights into pathogenesis and clinical diversity. Nat. Rev. Cancer 2014, 15, 25-41. [CrossRef] [PubMed]

11. Sauter, G.; Algaba, F.; Amin, M. Tumours of the Urinary System: Non-Invasive Urothelial Neoplasias. In HO Classification of Tumours of the Urinary System and Male Genital Organs; Eble, J.N., Sauter, G., Epstein, J., Sesterhenn, I., Eds.; IARCC Press: Lyon, France, 2004.

12. NICE (National Institute for Health and Care Excellence). Bladder Cancer: Diagnosis and Management; NICE (National Institute for Health and Care Excellence): London, UK, 2015.

13. Redelman-Sidi, G.; Glickman, M.S.; Bochner, B.H. The mechanism of action of BCG therapy for bladder cancer-A current perspective. Nat. Rev. Urol. 2014, 11, 153-162. [CrossRef] [PubMed]

14. Cheung, G.; Sahai, A.; Billia, M.; Dasgupta, P.; Khan, M.S. Recent advances in the diagnosis and treatment of bladder cancer. BMC Med. 2013, 11, 13. [CrossRef] [PubMed]

15. Xylinas, E.; Rink, M.; Margulis, V.; Karakiewicz, P.; Novara, G.; Shariat, S.F. Multifocal carcinoma in situ of the upper tract is associated with high risk of bladder cancer recurrence. Eur. Urol. 2012, 61, 1069-1070. [CrossRef] [PubMed]

16. Sylvester, R.J.; van der Meijden, A.P.M.; Oosterlinck, W.; Witjes, J.A.; Bouffioux, C.; Denis, L.; Newling, D.W.W.; Kurth, K. Predicting recurrence and progression in individual patients with stage Ta T1 bladder cancer using EORTC risk tables: A combined analysis of 2596 patients from seven EORTC trials. Eur. Urol. 2006, 49, 466-465. [PubMed]

17. Stenzl, A.; Cowan, N.C.; de Santis, M.; Kuczyk, M.A.; Merseburger, A.S.; Ribal, M.J.; Sherif, A.; Witjes, J.A. Treatment of muscle-invasive and metastatic bladder cancer: Update of the EAU guidelines. Eur. Urol. 2011, 59, 1009-1018. [CrossRef] [PubMed]

18. Karl, A.; Carroll, P.R.; Gschwend, J.E.; Knüchel, R.; Montorsi, F.; Stief, C.G.; Studer, U.E. The impact of lymphadenectomy and lymph node metastasis on the outcomes of radical cystectomy for bladder cancer. Eur. Urol. 2009, 55, 826-835. [CrossRef] [PubMed]

19. Platt, F.M.; Hurst, C.D.; Taylor, C.F.; Gregory, W.M.; Harnden, P.; Knowles, M.A. Spectrum of phosphatidylinositol 3-kinase pathway gene alterations in bladder cancer. Clin. Cancer Res. 2009, 15, 6008-6017. [CrossRef] [PubMed]

20. Kompier, L.C.; Lurkin, I.; van der Aa, M.N.M.; van Rhijn, B.W.G.; van der Kwast, T.H.; Zwarthoff, E.C. FGFR3, HRAS, KRAS, NRAS and PIK3CA mutations in bladder cancer and their potential as biomarkers for surveillance and therapy. PLOS ONE 2010, 5, e13821. [CrossRef] [PubMed] 
21. Dueñas, M.; Martínez-Fernández, M.; García-Escudero, R.; Villacampa, F.; Marqués, M.; Saiz-Ladera, C.; Duarte, J.; Martínez, V.; Gómez, M.J.; Martín, M.L.; et al. PIK3CA gene alterations in bladder cancer are frequent and associate with reduced recurrence in non-muscle invasive tumors. Mol. Carcinog. 2013. [CrossRef]

22. Ross, J.S.; Wang, K.; Al-Rohil, R.N.; Nazeer, T.; Sheehan, C.E.; Otto, G.A.; He, J.; Palmer, G.; Yelensky, R.; Lipson, D.; et al. Advanced urothelial carcinoma: Next-generation sequencing reveals diverse genomic alterations and targets of therapy. Mod. Pathol. 2014, 27, 271-280. [CrossRef] [PubMed]

23. Teo, M.T.W.; Dyrskjøt, L.; Nsengimana, J.; Buchwald, C.; Snowden, H.; Morgan, J.; Jensen, J.B.; Knowles, M.A.; Taylor, G.; Barrett, J. H.; et al. Next-generation sequencing identifies germline MRE11A variants as markers of radiotherapy outcomes in muscle-invasive bladder cancer. Ann. Oncol. 2014, 25, 877-883. [CrossRef] [PubMed]

24. The Cancer Genome Atlas Research Network. Available online: https://tcga-data.nci.nih.gov/tcga/ (accessed on 5 November 2015).

25. Damrauer, J.S.; Hoadley, K.A.; Chism, D.D.; Fan, C.; Tiganelli, C.J.; Wobker, S.E.; Yeh, J.J.; Milowsky, M.I.; Iyer, G.; Parker, J.S.; et al. Intrinsic subtypes of high-grade bladder cancer reflect the hallmarks of breast cancer biology. Proc. Natl. Acad. Sci. USA 2014, 111, 3110-3115. [CrossRef] [PubMed]

26. Sjödahl, G.; Lauss, M.; Lövgren, K.; Chebil, G.; Gudjonsson, S.; Veerla, S.; Patschan, O.; Aine, M.; Fernö, M.; Ringnér, M.; et al. A molecular taxonomy for urothelial carcinoma. Clin. Cancer Res. 2012, 18, 3377-3386. [CrossRef] [PubMed]

27. Choi, W.; Porten, S.; Kim, S.; Willis, D.; Plimack, E.R.; Hoffman-Censits, J.; Roth, B.; Cheng, T.; Tran, M.; Lee, I.-L.; et al. Identification of distinct basal and luminal subtypes of muscle-invasive bladder cancer with different sensitivities to frontline chemotherapy. Cancer Cell 2014, 25, 152-165. [CrossRef] [PubMed]

28. Aine, M.; Eriksson, P.; Liedberg, F.; Sjödahl, G.; Höglund, M. Biological determinants of bladder cancer gene expression subtypes. Sci. Rep. 2015, 5, 10957. [CrossRef] [PubMed]

29. Zeidler, M.; Varambally, S.; Cao, Q.; Chinnaiyan, A.M.; Ferguson, D.O.; Merajver, S.D.; Kleer, C.G. The Polycomb group protein EZH2 impairs DNA repair in breast epithelial cells. Neoplasia 2005, 7, 1011-1019. [CrossRef] [PubMed]

30. Yang, Y.A.; Yu, J. EZH2, an epigenetic driver of prostate cancer. Protein Cel. 2013, 4, 331-41. [CrossRef] [PubMed]

31. Grzenda, A.; Ordog, T.; Urrutia, R. Polycomb and the emerging epigenetics of pancreatic cancer. J. Gastrointest. Cancer 2011, 42, 100-111. [CrossRef] [PubMed]

32. Pfeifer, G.P.; Rauch, T.A. DNA methylation patterns in lung carcinomas. Semin. Cancer Biol. 2009, 19, 181-187. [CrossRef] [PubMed]

33. Sparmann, A.; van Lohuizen, M. Polycomb silencers control cell fate, development and cancer. Nat. Rev. Cancer 2006, 6, 846-856. [CrossRef] [PubMed]

34. Schuettengruber, B.; Chourrout, D.; Vervoort, M.; Leblanc, B.; Cavalli, G. Genome regulation by polycomb and trithorax proteins. Cell 2007, 128, 735-745. [CrossRef] [PubMed]

35. Deb, G.; Singh, A.K.; Gupta, S. EZH2: Not EZHY (easy) to deal. Mol. Cancer Res. 2014, 12, $639-653$. [CrossRef] [PubMed]

36. Yamaguchi, H.; Hung, M.-C. Regulation and Role of EZH2 in Cancer. Cancer Res. Treat. 2014, 46, $209-222$. [CrossRef] [PubMed]

37. Margueron, R.; Reinberg, D. The Polycomb complex PRC2 and its mark in life. Nature 2011, 469, 343-349. [CrossRef] [PubMed]

38. Crea, F.; Hurt, E.M.; Mathews, L.A.; Cabarcas, S.M.; Sun, L.; Marquez, V.E.; Danesi, R.; Farrar, W.L. Pharmacologic disruption of Polycomb Repressive Complex 2 inhibits tumorigenicity and tumor progression in prostate cancer. Mol. Cancer 2011, 10, 40. [CrossRef] [PubMed]

39. Pietersen, A.M.; Horlings, H.M.; Hauptmann, M.; Langerød, A.; Ajouaou, A.; Cornelissen-Steijger, P.; Wessels, L.F.; Jonkers, J.; van de Vijver, M.J.; van Lohuizen, M. EZH2 and BMI1 inversely correlate with prognosis and TP53 mutation in breast cancer. Breast Cancer Res. 2008, 10, R109. [CrossRef] [PubMed]

40. Cao, R.; Wang, L.; Wang, H.; Xia, L.; Erdjument-Bromage, H.; Tempst, P.; Jones, R.S.; Zhang, Y. Role of histone H3 lysine 27 methylation in Polycomb-group silencing. Science 2002, 298, 1039-1043. [CrossRef] [PubMed] 
41. Cao, R.; Zhang, Y. The functions of E(Z)/EZH2-mediated methylation of lysine 27 in histone H3. Curr. Opin. Genet. Dev. 2004, 14, 155-164. [CrossRef] [PubMed]

42. Simon, J.A.; Lange, C.A. Roles of the EZH2 histone methyltransferase in cancer epigenetics. Mutat. Res. 2008, 647, 21-29. [CrossRef] [PubMed]

43. Ciferri, C.; Lander, G.C.; Maiolica, A.; Herzog, F.; Aebersold, R.; Nogales, E. Molecular architecture of human polycomb repressive complex 2. Elife 2012, 1, e0005. [CrossRef] [PubMed]

44. Viré, E.; Brenner, C.; Deplus, R.; Blanchon, L.; Fraga, M.; Didelot, C.; Morey, L.; van Eynde, A.; Bernard, D.; Vanderwinden, J.-M.; et al. The Polycomb group protein EZH2 directly controls DNA methylation. Nature 2006, 439, 871-874. [CrossRef] [PubMed]

45. Kuzmichev, A.; Nishioka, K.; Erdjument-Bromage, H.; Tempst, P.; Reinberg, D. Histone methyltransferase activity associated with a human multiprotein complex containing the Enhancer of Zeste protein. Genes Dev. 2002, 16, 2893-2905. [CrossRef] [PubMed]

46. Kondo, Y.; Shen, L.; Cheng, A. S.; Ahmed, S.; Boumber, Y.; Charo, C.; Yamochi, T.; Urano, T.; Furukawa, K.; Kwabi-Addo, B.; et al. Gene silencing in cancer by histone H3 lysine 27 trimethylation independent of promoter DNA methylation. Nat. Genet. 2008, 40, 741-750. [CrossRef] [PubMed]

47. Sauvageau, M.; Sauvageau, G. Polycomb group proteins: Multi-faceted regulators of somatic stem cells and cancer. Cell Stem Cell 2010, 7, 299-313. [CrossRef] [PubMed]

48. Grzenda, A.; Lomberk, G.; Svingen, P.; Mathison, A.; Calvo, E.; Iovanna, J.; Xiong, Y.; Faubion, W.; Urrutia, R. Functional characterization of EZH2 $\beta$ reveals the increased complexity of EZH2 isoforms involved in the regulation of mammalian gene expression. Epigenet. Chromatin 2013, 6, 3. [CrossRef] [PubMed]

49. Asangani, I.A.; Ateeq, B.; Cao, Q.; Dodson, L.; Pandhi, M.; Kunju, L.P.; Mehra, R.; Lonigro, R.J.; Siddiqui, J.; Palanisamy, N.; et al. Characterization of the EZH2-MMSET histone methyltransferase regulatory axis in cancer. Mol. Cell. 2013, 49, 80-93. [CrossRef] [PubMed]

50. Cao, Q.; Mani, R.-S.; Ateeq, B.; Dhanasekaran, S.M.; Asangani, I.A.; Prensner, J.R.; Kim, J.H.; Brenner, J.C.; Jing, X.; Cao, X.; et al. Coordinated regulation of polycomb group complexes through microRNAs in cancer. Cancer Cell 2011, 20, 187-199. [CrossRef] [PubMed]

51. Hussain, M.; Rao, M.; Humphries, A.E.; Hong, J.A.; Liu, F.; Yang, M.; Caragacianu, D.; Schrump, D.S. Tobacco smoke induces polycomb-mediated repression of Dickkopf-1 in lung cancer cells. Cancer Res. 2009, 69, 3570-3578. [CrossRef] [PubMed]

52. Chang, C.-J.; Yang, J.-Y.; Xia, W.; Chen, C.-T.; Xie, X.; Chao, C.-H.; Woodward, W.A.; Hsu, J.-M.; Hortobagyi, G.N.; Hung, M.-C. EZH2 promotes expansion of breast tumor initiating cells through activation of RAF1- $\beta$-catenin signaling. Cancer Cell 2011, 19, 86-100. [CrossRef] [PubMed]

53. Gonzalez, M.E.; Li, X.; Toy, K.; DuPrie, M.; Ventura, A.C.; Banerjee, M.; Ljungman, M.; Merajver, S.D.; Kleer, C.G. Downregulation of EZH2 decreases growth of estrogen receptor-negative invasive breast carcinoma and requires BRCA1. Oncogene 2009, 28, 843-853. [CrossRef] [PubMed]

54. Fujii, S.; Fukamachi, K.; Tsuda, H.; Ito, K.; Ito, Y.; Ochiai, A. RAS oncogenic signal upregulates EZH2 in pancreatic cancer. Biochem. Biophys. Res. Commun. 2012, 417, 1074-1079. [CrossRef] [PubMed]

55. Min, J.; Zaslavsky, A.; Fedele, G.; McLaughlin, S.K.; Reczek, E.E.; de Raedt, T.; Guney, I.; Strochlic, D.E.; Macconaill, L.E.; Beroukhim, R.; et al. An oncogene-tumor suppressor cascade drives metastatic prostate cancer by coordinately activating Ras and nuclear factor-kappaB. Nat. Med. 2010, 16, 286-294. [CrossRef] [PubMed]

56. Xu, K.; Wu, Z.J.; Groner, A.C.; He, H.H.; Cai, C.; Lis, R.T.; Wu, X.; Stack, E.C.; Loda, M.; Liu, T.; et al. EZH2 oncogenic activity in castration-resistant prostate cancer cells is Polycomb-independent. Science 2012, 338, 1465-1469. [CrossRef] [PubMed]

57. Cha, T.-L.; Zhou, B.P.; Xia, W.; Wu, Y.; Yang, C.-C.; Chen, C.-T.; Ping, B.; Otte, A.P.; Hung, M.-C. Akt-mediated phosphorylation of EZH2 suppresses methylation of lysine 27 in histone H3. Science 2005, 310, 306-310. [CrossRef] [PubMed]

58. Kim, E.; Kim, M.; Woo, D.-H.; Shin, Y.; Shin, J.; Chang, N.; Oh, Y. T.; Kim, H.; Rheey, J.; Nakano, I.; et al. Phosphorylation of EZH2 activates STAT3 signaling via STAT3 methylation and promotes tumorigenicity of glioblastoma stem-like cells. Cancer Cell 2013, 23, 839-852. [CrossRef] [PubMed] 
59. Lee, J.M.; Lee, J.S.; Kim, H.; Kim, K.; Park, H.; Kim, J.-Y.; Lee, S.H.; Kim, I.S.; Kim, J.; Lee, M.; et al. EZH2 generates a methyl degron that is recognized by the DCAF1/DDB1/CUL4 E3 ubiquitin ligase complex. Mol. Cell 2012, 48, 572-586. [CrossRef] [PubMed]

60. Moretti, R.M.; Montagnani Marelli, M.; Motta, M.; Limonta, P. Role of the orphan nuclear receptor ROR $\alpha$ in the control of the metastatic behavior of androgen-independent prostate cancer cells. Oncol. Rep. 2002, 9, 1139-1143. [CrossRef] [PubMed]

61. Lee, J.M.; Kim, I.S.; Kim, H.; Lee, J.S.; Kim, K.; Yim, H.Y.; Jeong, J.; Kim, J.H.; Kim, J.-Y.; Lee, H.; et al. ROR $\alpha$ attenuates Wnt/ $\beta$-catenin signaling by PKC $\alpha$-dependent phosphorylation in colon cancer. Mol. Cell 2010, 37, 183-195. [CrossRef] [PubMed]

62. He, A.; Shen, X.; Ma, Q.; Cao, J.; von Gise, A.; Zhou, P.; Wang, G.; Marquez, V.E.; Orkin, S.H.; Pu, W.T. PRC2 directly methylates GATA4 and represses its transcriptional activity. Genes Dev. 2012, 26, 37-42. [CrossRef] [PubMed]

63. Tan, J.; Yan, Y.; Wang, X.; Jiang, Y.; Xu, H.E. EZH2: Biology, disease, and structure-based drug discovery. Acta Pharmacol. Sin. 2014, 35, 161-174. [CrossRef] [PubMed]

64. Shi, B.; Liang, J.; Yang, X.; Wang, Y.; Zhao, Y.; Wu, H.; Sun, L.; Zhang, Y.; Chen, Y.; Li, R.; et al. Integration of estrogen and Wnt signaling circuits by the polycomb group protein EZH2 in breast cancer cells. Mol. Cell. Biol. 2007, 27, 5105-5119. [CrossRef] [PubMed]

65. Lee, S.T.; Li, Z.; Wu, Z.; Aau, M.; Guan, P.; Karuturi, R.K.M.; Liou, Y.C.; Yu, Q. Context-specific regulation of NF-кB target gene expression by EZH2 in breast cancers. Mol. Cell 2011, 43, 798-810. [CrossRef] [PubMed]

66. Jung, H.-Y.; Jun, S.; Lee, M.; Kim, H.-C.; Wang, X.; Ji, H.; McCrea, P.D.; Park, J.-I. PAF and EZH2 induce Wnt/ $\beta$-catenin signaling hyperactivation. Mol. Cell 2013, 52, 193-205. [CrossRef] [PubMed]

67. Yan, J.; Ng, S.-B.; Tay, J.L.-S.; Lin, B.; Koh, T.L.; Tan, J.; Selvarajan, V.; Liu, S.-C.; Bi, C.; Wang, S.; et al. EZH2 overexpression in natural killer/T-cell lymphoma confers growth advantage independently of histone methyltransferase activity. Blood 2013, 121, 4512-4520. [CrossRef] [PubMed]

68. Mitra, A.P.; Pagliarulo, V.; Yang, D.; Waldman, F.M.; Datar, R.H.; Skinner, D.G.; Groshen, S.; Cote, R.J. Generation of a Concise gene panel for outcome prediction in urinary bladder cancer. J. Clin. Oncol. 2009, 27, 3929-3937. [CrossRef] [PubMed]

69. Chan, K.S.; Espinosa, I.; Chao, M.; Wong, D.; Ailles, L.; Diehn, M.; Gill, H.; Presti, J.; Chang, H. Y.; van de Rijn, M.; et al. Identification, molecular characterization, clinical prognosis, and therapeutic targeting of human bladder tumor-initiating cells. Proc. Natl. Acad. Sci. USA 2009, 106, 14016-14021. [CrossRef] [PubMed]

70. Ho, P.L.; Lay, E.J.; Jian, W.; Parra, D.; Chan, K.S. STAT3 activation in urothelial stem cells leads to direct progression to invasive bladder cancer. Cancer Res. 2012, 72, 3135-3142. [CrossRef] [PubMed]

71. Guo, Y.; Ying, L.; Tian, Y.; Yang, P.; Zhu, Y.; Wang, Z.; Qiu, F.; Lin, J. miR-144 downregulation increases bladder cancer cell proliferation by targeting EZH2 and regulating Wnt signaling. FEBS J. 2013, 280, 4531-4538. [CrossRef] [PubMed]

72. Bachmann, I.M.; Halvorsen, O.J.; Collett, K.; Stefansson, I.M.; Straume, O.; Haukaas, S.A.; Salvesen, H.B.; Otte, A.P.; Akslen, L.A. EZH2 expression is associated with high proliferation rate and aggressive tumor subgroups in cutaneous melanoma and cancers of the endometrium, prostate, and breast. J. Clin. Oncol. 2006, 24, 268-273. [CrossRef] [PubMed]

73. Gupta, P.B.; Fillmore, C.M.; Jiang, G.; Shapira, S.D.; Tao, K.; Kuperwasser, C.; Lander, E.S. Stochastic state transitions give rise to phenotypic equilibrium in populations of cancer cells. Cell 2011, 146, 633-644. [CrossRef] [PubMed]

74. Bracken, A.P.; Pasini, D.; Capra, M.; Prosperini, E.; Colli, E.; Helin, K. EZH2 is downstream of the pRB-E2F pathway, essential for proliferation and amplied in cancer. EMBO J. 2003, 22, 5323-5335. [CrossRef] [PubMed]

75. Koh, C.M.; Iwata, T.; Zheng, Q.; Bethel, C.; Yegnasubramanian, S.; de Marzo, A.M. Myc enforces overexpression of EZH2 in early prostatic neoplasia via transcriptional and post-transcriptional mechanisms. Oncotarget 2011, 2, 669-683. [CrossRef] [PubMed]

76. Neri, F.; Zippo, A.; Krepelova, A.; Cherubini, A.; Rocchigiani, M. Oliviero, S. Myc regulates the transcription of the PRC2 gene to control the expression of developmental genes in embryonic stem cells. Mol. Cell. Biol. 2012, 32, 840-851. [CrossRef] [PubMed] 
77. Tang, X.; Milyavsky, M.; Shats, I.; Erez, N.; Goldfinger, N. Rotter, V. Activated p53 suppresses the histone methyltransferase EZH2 gene. Oncogene 2004, 23, 5759-5769. [CrossRef] [PubMed]

78. Benetatos, L.; Voulgaris, E.; Vartholomatos, G.; Hatzimichael, E. Non-coding RNAs and EZH2 interactions in cancer: Long and short tales from the transcriptome. Int. J. Cancer 2013, 133, 267-274. [CrossRef] [PubMed]

79. Wu, S.C.; Zhang, Y. Cyclin-dependent kinase 1 (CDK1)-mediated phosphorylation of enhancer of zeste 2 (Ezh2) regulates its stability. J. Biol. Chem. 2011, 286, 28511-28519. [CrossRef] [PubMed]

80. Riising, E.M.; Boggio, R.; Chiocca, S.; Helin, K. Pasini, D. The polycomb repressive complex 2 is a potential target of SUMO modifications. PLoS ONE 2008, 3, e2704. [CrossRef] [PubMed]

81. Kaur, M.; Cole, M.D. MYC Acts via the PTEN Tumor Suppressor to Elicit Autoregulation and Genome-Wide Gene Repression by Activation of the Ezh2 Methyltransferase. Cancer Res. 2012, 73, 695-705. [CrossRef] [PubMed]

82. Wang, L.; Zhang, X.; Jia, L.-T.; Hu, S.-J.; Zhao, J.; Yang, J.-D.; Wen, W.-H.; Wang, Z.; Wang, T.; Zhao, J.; et al. c-Myc-mediated epigenetic silencing of MicroRNA-101 contributes to dysregulation of multiple pathways in hepatocellular carcinoma. Hepatology 2014, 59, 1850-1863. [CrossRef] [PubMed]

83. Sander, S.; Bullinger, L.; Klapproth, K.; Fiedler, K.; Kestler, H.A.; Barth, T.F.E.; Möller, P.; Stilgenbauer, S.; Pollack, J.R.; Wirth, T. MYC stimulates EZH2 expression by repression of its negative regulator miR-26a. Blood 2008, 112, 4202-4212. [CrossRef] [PubMed]

84. Ma, M.-Z.; Li, C.-X.; Zhang, Y.; Weng, M.-Z.; Zhang, M.; Qin, Y.-Y.; Gong, W.; Quan, Z.-W. Long non-coding RNA HOTAIR, a c-Myc activated driver of malignancy, negatively regulates miRNA-130a in gallbladder cancer. Mol. Cancer 2014, 13, 156. [CrossRef] [PubMed]

85. Kaneko, S.; Li, G.; Son, J.; Xu, C.-F.; Margueron, R.; Neubert, T.A.; Reinberg, D. Phosphorylation of the PRC2 component Ezh2 is cell cycle-regulated and up-regulates its binding to ncRNA. Genes Dev. 2010, 24, 2615-2620. [CrossRef] [PubMed]

86. Tsai, M.-C.; Manor, O.; Wan, Y.; Mosammaparast, N.; Wang, J.K.; Lan, F.; Shi, Y.; Segal, E.; Chang, H.Y. Long noncoding RNA as modular scaffold of histone modification complexes. Science 2010, 329, 689-693. [CrossRef] [PubMed]

87. Calin, G.A.; Croce, C.M. MicroRNA signatures in human cancers. Nat. Rev. Cancer 2006, 6, 857-866. [CrossRef] [PubMed]

88. Croce, C.M. Causes and consequences of microRNA dysregulation in cancer. Nat. Rev. Genet. 2009, 10, 704-714. [CrossRef] [PubMed]

89. Guil, S.; Esteller, M. DNA methylomes, histone codes and miRNAs: Tying it all together. Int. J. Biochem. Cell. Biol. 2009, 41, 87-95. [CrossRef] [PubMed]

90. Hatziapostolou, M.; Iliopoulos, D. Epigenetic aberrations during oncogenesis. Cell. Mol. Life Sci. 2011, 68, 1681-1702. [CrossRef] [PubMed]

91. Rinn, J.L.; Chang, H.Y. Genome regulation by long noncoding RNAs. Annu. Rev. Biochem. 2012, 81, 145-166. [CrossRef] [PubMed]

92. Guttman, M.; Rinn, J.L. Modular regulatory principles of large non-coding RNAs. Nature 2012, 482, 339-346. [CrossRef] [PubMed]

93. Gibb, E.A.; Brown, C.J.; Lam, W.L. The functional role of long non-coding RNA in human carcinomas. Mol. Cancer 2011, 10, 38. [CrossRef] [PubMed]

94. Willingham, A.T.; Orth, A.P.; Batalov, S.; Peters, E.C.; Wen, B.G.; Aza-Blanc, P.; Hogenesch, J.B.; Schultz, P.G. A strategy for probing the function of noncoding RNAs finds a repressor of NFAT. Science 2005, 309, 1570-1573. [CrossRef] [PubMed]

95. Sleutels, F.; Zwart, R.; Barlow, D.P. The non-coding Air RNA is required for silencing autosomal imprinted genes. Nature 2002, 415, 810-813. [CrossRef] [PubMed]

96. Mancini-Dinardo, D.; Steele, S.J.S.; Levorse, J.M.; Ingram, R.S.; Tilghman, S.M. Elongation of the Kcnq1ot1 transcript is required for genomic imprinting of neighboring genes. Genes Dev. 2006, 20, 1268-1282. [CrossRef] [PubMed]

97. Brown, C.J.; Ballabio, A.; Rupert, J.L.; Lafreniere, R.G.; Grompe, M.; Tonlorenzi, R.; Willard, H.F. A gene from the region of the human $X$ inactivation centre is expressed exclusively from the inactive $X$ chromosome. Nature 1991, 349, 38-44. [CrossRef] [PubMed] 
98. Cesana, M.; Cacchiarelli, D.; Legnini, I.; Santini, T.; Sthandier, O.; Chinappi, M.; Tramontano, A.; Bozzoni, I. A long noncoding RNA controls muscle differentiation by functioning as a competing endogenous RNA. Cell 2011, 147, 358-369. [CrossRef] [PubMed]

99. Varambally, S.; Cao, Q.; Mani, R.-S.; Shankar, S.; Wang, X.; Ateeq, B.; Laxman, B.; Cao, X.; Jing, X.; Ramnarayanan, K.; et al. Genomic loss of microRNA-101 leads to overexpression of histone methyltransferase EZH2 in cancer. Science 2008, 322, 1695-1699. [CrossRef] [PubMed]

100. Juan, A.H.; Kumar, R.M.; Marx, J.G.; Young, R.A.; Sartorelli, V. Mir-214-dependent regulation of the polycomb protein EZH2 in skeletal muscle and embryonic stem cells. Mol. Cell 2009, 36, 61-74. [CrossRef] [PubMed]

101. Zhang, J.; Guo, J.-F.; Liu, D.-L.; Liu, Q.; Wang, J.-J. MicroRNA-101 exerts tumor-suppressive functions in non-small cell lung cancer through directly targeting enhancer of zeste homolog 2. J. Thorac. Oncol. 2011, 6, 671-678. [CrossRef] [PubMed]

102. Esposito, F.; Tornincasa, M.; Pallante, P.; Federico, A.; Borbone, E.; Pierantoni, G.M.; Fusco, A. Down-regulation of the miR-25 and miR-30d contributes to the development of anaplastic thyroid carcinoma targeting the polycomb protein EZH2. J. Clin. Endocrinol. Metab. 2012, 97, E710-E718. [CrossRef] [PubMed]

103. Tsukigi, M.; Bilim, V.; Yuuki, K.; Ugolkov, A.; Naito, S.; Nagaoka, A.; Kato, T.; Motoyama, T.; Tomita, Y. Re-expression of miR-199a suppresses renal cancer cell proliferation and survival by targeting GSK-3 $\beta$. Cancer Lett. 2012, 315, 189-197. [CrossRef] [PubMed]

104. Kong, D.; Heath, E.; Chen, W.; Cher, M. L.; Powell, I.; Heilbrun, L.; Li, Y.; Ali, S.; Sethi, S.; Hassan, O.; et al. Loss of let-7 up-regulates EZH2 in prostate cancer consistent with the acquisition of cancer stem cell signatures that are attenuated by BR-DIM. PLoS ONE 2012, 7, e33729. [CrossRef] [PubMed]

105. Li, L.; Liu, B.; Wapinski, O.L.; Tsai, M.-C.; Qu, K.; Zhang, J.; Carlson, J. C.; Lin, M.; Fang, F.; Gupta, R.A.; et al . Targeted disruption of HOTAIR leads to homeotic transformation and gene derepression. Cell. Rep. 2013, 5, 3-12. [CrossRef] [PubMed]

106. Zhang, H.; Zhang, H.; Zhao, M.; Lv, Z.; Zhang, X.; Qin, X.; Wang, H.; Wang, S.; Su, J.; Lv, X.; et al. MiR-138 inhibits tumor growth through repression of EZH2 in non-small cell lung cancer. Cell. Physiol. Biochem. 2013, 31, 56-65. [CrossRef] [PubMed]

107. Huang, S.-D.; Yuan, Y.; Zhuang, C.-W.; Li, B.-L.; Gong, D.-J.; Wang, S.-G.; Zeng, Z.-Y.; Cheng, H.-Z. MicroRNA-98 and microRNA-214 post-transcriptionally regulate enhancer of zeste homolog 2 and inhibit migration and invasion in human esophageal squamous cell carcinoma. Mol. Cancer 2012, 11, 51. [CrossRef] [PubMed]

108. Wang, H.-J.; Ruan, H.-J.; He, X.-J.; Ma, Y.-Y.; Jiang, X.-T.; Xia, Y.-J.; Ye, Z.-Y.; Tao, H.-Q. MicroRNA-101 is down-regulated in gastric cancer and involved in cell migration and invasion. Eur. J. Cancer 2010, 46, 2295-303. [CrossRef] [PubMed]

109. Nakahara, O.; Takamori, H.; Iwatsuki, M.; Baba, Y.; Sakamoto, Y.; Tanaka, H.; Chikamoto, A.; Horino, K.; Beppu, T.; Kanemitsu, K.; et al. Carcinogenesis of intraductal papillary mucinous neoplasm of the pancreas: Loss of microRNA-101 promotes overexpression of histone methyltransferase EZH2. Ann. Surg. Oncol. 2012, 19 (Suppl. 3), S565-S571. [CrossRef] [PubMed]

110. Friedman, J.M.; Liang, G.; Liu, C.-C.; Wolff, E.M.; Tsai, Y.C.; Ye, W.; Zhou, X.; Jones, P.A. The putative tumor suppressor microRNA-101 modulates the cancer epigenome by repressing the polycomb group protein EZH2. Cancer Res. 2009, 69, 2623-2629. [CrossRef] [PubMed]

111. Tzatsos, A.; Paskaleva, P.; Lymperi, S.; Contino, G.; Stoykova, S.; Chen, Z.; Wong, K.-K.; Bardeesy, N. Lysine-specific demethylase 2B (KDM2B)-let-7-enhancer of zester homolog 2 (EZH2) pathway regulates cell cycle progression and senescence in primary cells. J. Biol. Chem. 2011, 286, 33061-33069. [CrossRef] [PubMed]

112. Kottakis, F.; Polytarchou, C.; Foltopoulou, P.; Sanidas, I.; Kampranis, S.C.; Tsichlis, P.N. FGF-2 regulates cell proliferation, migration, and angiogenesis through an NDY1/KDM2B-miR-101-EZH2 pathway. Mol. Cell 2011, 43, 285-298. [CrossRef] [PubMed]

113. Zhang, Q.; Padi, S.K.R.; Tindall, D.J.; Guo, B. Polycomb protein EZH2 suppresses apoptosis by silencing the proapoptotic miR-31. Cell. Death Dis. 2014, 5, e1486. [CrossRef] [PubMed] 
114. Au, S.L.-K.; Wong, C.C.-L.; Lee, J. M.-F.; Fan, D.N.-Y.; Tsang, F.H.; Ng, I.O.-L.; Wong, C.-M. Enhancer of zeste homolog 2 epigenetically silences multiple tumor suppressor microRNAs to promote liver cancer metastasis. Hepatology 2012, 56, 622-631. [CrossRef] [PubMed]

115. Prensner, J.R.; Iyer, M.K.; Balbin, O.A.; Dhanasekaran, S.M.; Cao, Q.; Brenner, J.C.; Laxman, B.; Asangani, I.A.; Grasso, C.S.; Kominsky, H.D.; et al. Transcriptome sequencing across a prostate cancer cohort identifies PCAT-1, an unannotated lincRNA implicated in disease progression. Nat. Biotechnol. 2011, 29, 742-749. [CrossRef] [PubMed]

116. Liu, L.; Qiu, M.; Tan, G.; Liang, Z.; Qin, Y.; Chen, L.; Chen, H.; Liu, J. miR-200c inhibits invasion, migration and proliferation of bladder cancer cells through down-regulation of BMI-1 and E2F3. J. Transl. Med. 2014, 12, 305. [CrossRef] [PubMed]

117. Santos, M.; Martínez-Fernández, M.; Dueñas, M.; García-Escudero, R.; Alfaya, B.; Villacampa, F.; Saiz-Ladera, C.; Costa, C.; Oteo, M.; Duarte, J.; et al. In vivo disruption of an Rb-E2F-EZH2 signaling loop causes bladder cancer. Cancer Res. 2014, 74, 6565-6577. [CrossRef] [PubMed]

118. Wiklund, E.D.; Bramsen, J.B.; Hulf, T.; Dyrskjøt, L.; Ramanathan, R.; Hansen, T.B.; Villadsen, S.B.; Gao, S.; Ostenfeld, M.S.; Borre, M.; et al. Coordinated epigenetic repression of the miR-200 family and miR-205 in invasive bladder cancer. Int. J. Cancer 2011, 128, 1327-1334. [CrossRef] [PubMed]

119. Martínez-Fernández, M.; Dueñas, M.; Feber, A.; Segovia, C.; García-Escudero, R.; Rubio, C.; López-Calderón, F.F.; Díaz-García, C.; Villacampa, F.; Duarte, J.; et al. A Polycomb-miR200 loop regulates clinical outcome in bladder cancer. Oncotarget 2015. in press.

120. Wang, J.; Zhang, X.; Wang, L.; Dong, Z.; Du, L.; Yang, Y.; Guo, Y.; Wang, C. Downregulation of urinary cell-free microRNA-214 as a diagnostic and prognostic biomarker in bladder cancer. J. Surg. Oncol. 2015, 111, 992-999. [CrossRef] [PubMed]

121. Xie, L.; Zhang, Z.; Tan, Z.; He, R.; Zeng, X.; Xie, Y.; Li, S.; Tang, G.; Tang, H.; He, X. MicroRNA-124 inhibits proliferation and induces apoptosis by directly repressing EZH2 in gastric cancer. Mol. Cell. Biochem. 2014, 392, 153-159. [CrossRef] [PubMed]

122. Neo, W.H.; Yap, K.; Lee, S.H.; Looi, L.S.; Khandelia, P.; Neo, S.X.; Makeyev, E.V.; Su, I. MicroRNA miR-124 controls the choice between neuronal and astrocyte differentiation by fine-tuning EZH2 expression. J. Biol. Chem. 2014, 289, 20788-20801. [CrossRef] [PubMed]

123. Zheng, F.; Liao, Y.-J.; Cai, M.-Y.; Liu, Y.-H.; Liu, T.-H.; Chen, S.-P.; Bian, X.-W.; Guan, X.-Y.; Lin, M.C.; Zeng, Y.-X.; et al. The putative tumour suppressor microRNA-124 modulates hepatocellular carcinoma cell aggressiveness by repressing ROCK2 and EZH2. Gut 2012, 61, 278-289. [CrossRef] [PubMed]

124. Xiu, Y.; Liu, Z.; Xia, S.; Jin, C.; Yin, H.; Zhao, W.; Wu, Q. MicroRNA-137 upregulation increases bladder cancer cell proliferation and invasion by targeting PAQR3. PLoS ONE 2014, 9, e109734. [CrossRef] [PubMed]

125. Xu, X.; Li, S.; Lin, Y.; Chen, H.; Hu, Z.; Mao, Y.; Xu, X.; Wu, J.; Zhu, Y.; Zheng, X.; et al. MicroRNA-124-3p inhibits cell migration and invasion in bladder cancer cells by targeting ROCK1. J. Transl. Med. 2013, 11, 276. [CrossRef] [PubMed]

126. Kunej, T.; Godnic, I.; Ferdin, J.; Horvat, S.; Dovc, P.; Calin, G.A. Epigenetic regulation of microRNAs in cancer: An integrated review of literature. Mutat. Res. Mol. Mech. Mutagen. 2011, 717, 77-84. [CrossRef] [PubMed]

127. Atkinson, S.P.; Koch, C.M.; Clelland, G.K.; Willcox, S.; Fowler, J.C.; Stewart, R.; Lako, M.; Dunham, I.; Armstrong, L. Epigenetic marking prepares the human HOXA cluster for activation during differentiation of pluripotent cells. Stem Cells 2008, 26, 1174-1185. [CrossRef] [PubMed]

128. Nagano, T.; Mitchell, J.A.; Sanz, L.A.; Pauler, F.M.; Ferguson-Smith, A.C.; Feil, R.; Fraser, P. The Air noncoding RNA epigenetically silences transcription by targeting G9a to chromatin. Science 2008, 322, 1717-1720. [CrossRef] [PubMed]

129. Bonasio, R.; Tu, S.; Reinberg, D. Molecular signals of epigenetic states. Science 2010, 330, 612-616. [CrossRef] [PubMed]

130. Luo, M.; Li, Z.; Wang, W.; Zeng, Y.; Liu, Z.; Qiu, J. Long non-coding RNA H19 increases bladder cancer metastasis by associating with EZH2 and inhibiting E-cadherin expression. Cancer Lett. 2013, 333, $213-221$. [CrossRef] [PubMed] 
131. He, W.; Cai, Q.; Sun, F.; Zhong, G.; Wang, P.; Liu, H.; Luo, J.; Yu, H.; Huang, J.; Lin, T. linc-UBC1 physically associates with polycomb repressive complex 2 (PRC2) and acts as a negative prognostic factor for lymph node metastasis and survival in bladder cancer. Biochim. Biophys. Acta 2013, 1832, 1528-1537. [CrossRef] [PubMed]

132. Yap, K.L.; Li, S.; Muñoz-Cabello, A.M.; Raguz, S.; Zeng, L.; Mujtaba, S.; Gil, J.; Walsh, M.J.; Zhou, M.-M. Molecular interplay of the noncoding RNA ANRIL and methylated histone H3 lysine 27 by polycomb CBX7 in transcriptional silencing of INK4a. Mol. Cell 2010, 38, 662-674. [CrossRef] [PubMed]

133. Tano, K.; Akimitsu, N. Long non-coding RNAs in cancer progression. Front. Genet. 2012, 3, 219. [CrossRef] [PubMed]

134. Kotake, Y.; Nakagawa, T.; Kitagawa, K.; Suzuki, S.; Liu, N.; Kitagawa, M.; Xiong, Y. Long non-coding RNA ANRIL is required for the PRC2 recruitment to and silencing of p15(INK4B) tumor suppressor gene. Oncogene 2011, 30, 1956-1962. [CrossRef] [PubMed]

135. Martínez-Fernández, M.; Feber, A.; Dueñas, M.; Segovia, C.; Rubio, C.; Fernandez, M.; Villacampa, F.; Duarte, J.; Lopez-Calderon, F.F.; Gomez-Rodriguez, M.J.; et al. Analysis of the Polycomb-related lncRNAs HOTAIR and ANRIL in bladder cancer. Clin. Epigenet. 2015. in press.

136. Geng, Y.J.; Xie, S.L.; Li, Q.; Ma, J.; Wang, G.Y. Large intervening non-coding RNA HOTAIR is associated with hepatocellular carcinoma progression. J. Int. Med. Res. 2011, 39, 2119-2128. [CrossRef] [PubMed]

137. Kogo, R.; Shimamura, T.; Mimori, K.; Kawahara, K.; Imoto, S.; Sudo, T.; Tanaka, F.; Shibata, K.; Suzuki, A.; Komune, S.; et al. Long noncoding RNA HOTAIR regulates polycomb-dependent chromatin modification and is associated with poor prognosis in colorectal cancers. Cancer Res. 2011, 71, 6320-6326. [CrossRef] [PubMed]

138. Gupta, R.A.; Shah, N.; Wang, K.C.; Kim, J.; Horlings, H.M.; Wong, D.J.; Tsai, M.-C.; Hung, T.; Argani, P.; Rinn, J.L.; et al. Long non-coding RNA HOTAIR reprograms chromatin state to promote cancer metastasis. Nature 2010, 464, 1071-1076. [CrossRef] [PubMed]

139. Li, J.; Wang, Y.; Yu, J.; Dong, R.; Qiu, H. A high level of circulating HOTAIR is associated with progression and poor prognosis of cervical cancer. Tumour Biol. 2014, 36, 1661-1665. [CrossRef] [PubMed]

140. Zhuang, Y.; Nguyen, H.T.; Burow, M.E.; Zhuo, Y.; El-Dahr, S.S.; Yao, X.; Cao, S.; Flemington, E.K.; Nephew, K.P.; Fang, F.; et al. Elevated expression of long intergenic non-coding RNA HOTAIR in a basal-like variant of MCF-7 breast cancer cells. Mol. Carcinog. 2014, 54, 1656-1667. [CrossRef] [PubMed]

141. Schorderet, P.; Duboule, D. Structural and functional differences in the long non-coding RNA HOTAIR in mouse and human. PLoS Genet. 2011, 7, e1002071. [CrossRef] [PubMed]

142. Kwon, M.J.; Shin, Y.K. Epigenetic regulation of cancer-associated genes in ovarian cancer. Int. J. Mol. Sci. 2011, 12, 983-1008. [CrossRef] [PubMed]

143. Gal-Yam, E.N.; Egger, G.; Iniguez, L.; Holster, H.; Einarsson, S.; Zhang, X.; Lin, J.C.; Liang, G.; Jones, P.A.; Tanay, A. Frequent switching of Polycomb repressive marks and DNA hypermethylation in the PC3 prostate cancer cell line. Proc. Natl. Acad. Sci. USA 2008, 105, 12979-12984. [CrossRef] [PubMed]

144. Ning, X.; Shi, Z.; Liu, X.; Zhang, A.; Han, L.; Jiang, K.; Kang, C.; Zhang, Q. DNMT1 and EZH2 mediated methylation silences the microRNA-200b/a/429 gene and promotes tumor progression. Cancer Lett. 2015, 359, 198-205. [CrossRef] [PubMed]

145. Voigt, P.; LeRoy, G.; Drury, W.J.; Zee, B.M.; Son, J.; Beck, D.B.; Young, N.L.; Garcia, B.A.; Reinberg, D. Asymmetrically modified nucleosomes. Cell 2012, 151, 181-193. [CrossRef] [PubMed]

146. LeRoy, G.; Chepelev, I.; DiMaggio, P.A.; Blanco, M.A.; Zee, B.M.; Zhao, K.; Garcia, B.A. Proteogenomic characterization and mapping of nucleosomes decoded by Brd and HP1 proteins. Genome Biol. 2012, 13, R68. [CrossRef] [PubMed]

147. Escamilla-Del-Arenal, M.; da Rocha, S.T.; Spruijt, C.G.; Masui, O.; Renaud, O.; Smits, A.H.; Margueron, R.; Vermeulen, M.; Heard, E. Cdyl, a new partner of the inactive $\mathrm{X}$ chromosome and potential reader of H3K27me3 and H3K9me2. Mol. Cell. Biol. 2013, 33, 5005-5020. [CrossRef] [PubMed]

148. Boros, J.; Arnoult, N.; Stroobant, V.; Collet, J.-F.; Decottignies, A. Polycomb repressive complex 2 and H3K27me3 cooperate with H3K9 methylation to maintain heterochromatin protein $1 \alpha$ at chromatin. Mol. Cell. Biol. 2014, 34, 3662-3674. [CrossRef] [PubMed]

149. Mozzetta, C.; Pontis, J.; Fritsch, L.; Robin, P.; Portoso, M.; Proux, C.; Margueron, R.; Ait-Si-Ali, S. The histone H3 lysine 9 methyltransferases G9a and GLP regulate polycomb repressive complex 2-mediated gene silencing. Mol. Cell 2014, 53, 277-289. [CrossRef] [PubMed] 
150. Shankar, S.R.; Bahirvani, A.G.; Rao, V.K.; Bharathy, N.; Ow, J.R.; Taneja, R. G9a, a multipotent regulator of gene expression. Epigenetics 2013, 8, 16-22. [CrossRef] [PubMed]

151. Roger, T.; Lugrin, J.; Le Roy, D.; Goy, G.; Mombelli, M.; Koessler, T.; Ding, X.C.; Chanson, A.-L.; Reymond, M.K.; Miconnet, I.; et al. Histone deacetylase inhibitors impair innate immune responses to Toll-like receptor agonists and to infection. Blood 2011, 117, 1205-1217. [CrossRef] [PubMed]

152. Niegisch, G.; Knievel, J.; Koch, A.; Hader, C.; Fischer, U.; Albers, P.; Schulz, W.A. Changes in histone deacetylase (HDAC) expression patterns and activity of HDAC inhibitors in urothelial cancers. Urol. Oncol. 2013, 31, 1770-1779. [CrossRef] [PubMed]

153. Lehmann, M.; Hoffmann, M.J.; Koch, A.; Ulrich, S.M.; Schulz, W.A.; Niegisch, G. Histone deacetylase 8 is deregulated in urothelial cancer but not a target for efficient treatment. J. Exp. Clin. Cancer Res. 2014, 33, 59. [CrossRef] [PubMed]

154. Poyet, C.; Jentsch, B.; Hermanns, T.; Schweckendiek, D.; Seifert, H.-H.; Schmidtpeter, M.; Sulser, T.; Moch, H.; Wild, P.J.; Kristiansen, G. Expression of histone deacetylases 1, 2 and 3 in urothelial bladder cancer. BMC Clin. Pathol. 2014, 14, 10. [CrossRef] [PubMed]

155. Kleer, C.G.; Cao, Q.; Varambally, S.; Shen, R.; Ota, I.; Tomlins, S.A.; Ghosh, D.; Sewalt, R.G.A.B.; Otte, A.P.; Hayes, D.F.; et al. EZH2 is a marker of aggressive breast cancer and promotes neoplastic transformation of breast epithelial cells. Proc. Natl. Acad. Sci. USA 2003, 100, 11606-11611. [CrossRef] [PubMed]

156. Varambally, S.; Dhanasekaran, S.M.; Zhou, M.; Barrette, T.R.; Kumar-Sinha, C.; Sanda, M.G.; Ghosh, D.; Pienta, K.J.; Sewalt, R.G.A.B.; Otte, A.P.; et al. The polycomb group protein EZH2 is involved in progression of prostate cancer. Nature 2002, 419, 624-629. [CrossRef] [PubMed]

157. Varier, R.A.; Timmers, H.T.M. Histone lysine methylation and demethylation pathways in cancer. Biochim. Biophys. Acta 2011, 1815, 75-89. [CrossRef] [PubMed]

158. Shi, Y.; Lan, F.; Matson, C.; Mulligan, P.; Whetstine, J.R.; Cole, P.A.; Casero, R.A.; Shi, Y. Histone demethylation mediated by the nuclear amine oxidase homolog LSD1. Cell 2004, 119, 941-953. [CrossRef] [PubMed]

159. Rotili, D.; Mai, A. Targeting histone demethylases: A new avenue for the fight against cancer. Genes Cancer 2011, 2, 663-679. [CrossRef] [PubMed]

160. Agger, K.; Cloos, P.A.C.; Christensen, J.; Pasini, D.; Rose, S.; Rappsilber, J.; Issaeva, I.; Canaani, E.; Salcini, A.E.; Helin, K. UTX and JMJD3 are histone H3K27 demethylases involved in HOX gene regulation and development. Nature 2007, 449, 731-734. [CrossRef]

161. Hong, S.; Cho, Y.-W.; Yu, L.-R.; Yu, H.; Veenstra, T.D.; Ge, K. Identification of JmjC domain-containing UTX and JMJD3 as histone H3 lysine 27 demethylases. Proc. Natl. Acad. Sci. USA 2007, 104, 18439-18444. [CrossRef] [PubMed]

162. Lan, F.; Bayliss, P.E.; Rinn, J.L.; Whetstine, J.R.; Wang, J.K.; Chen, S.; Iwase, S.; Alpatov, R.; Issaeva, I.; Canaani, E.; et al. A histone H3 lysine 27 demethylase regulates animal posterior development. Nature 2007, 449, 689-694. [CrossRef] [PubMed]

163. Lee, M.G.; Villa, R.; Trojer, P.; Norman, J.; Yan, K.-P.; Reinberg, D.; di Croce, L.; Shiekhattar, R. Demethylation of H3K27 regulates polycomb recruitment and H2A ubiquitination. Science 2007, 318, 447-450. [CrossRef] [PubMed]

164. Van Haaften, G.; Dalgliesh, G.L.; Davies, H.; Chen, L.; Bignell, G.; Greenman, C.; Edkins, S.; Hardy, C.; O'Meara, S.; Teague, J.; et al. Somatic mutations of the histone H3K27 demethylase gene UTX in human cancer. Nat. Genet. 2009, 41, 521-523. [CrossRef] [PubMed]

165. Tian, X.; Zhang, S.; Liu, H.-M.; Zhang, Y.-B.; Blair, C.A.; Mercola, D.; Sassone-Corsi, P.; Zi, X. Histone lysine-specific methyltransferases and demethylases in carcinogenesis: New targets for cancer therapy and prevention. Curr. Cancer Drug Targets 2013, 13, 558-579. [CrossRef] [PubMed]

166. Gui, Y.; Guo, G.; Huang, Y.; Hu, X.; Tang, A.; Gao, S.; Wu, R.; Chen, C.; Li, X.; Zhou, L.; et al. Frequent mutations of chromatin remodeling genes in transitional cell carcinoma of the bladder. Nat. Genet. 2011, 43, 875-878. [CrossRef] [PubMed]

167. Nickerson, M.L.; Dancik, G.M.; Im, K.M.; Edwards, M.G.; Turan, S.; Brown, J.; Ruiz-Rodriguez, C.; Owens, C.; Costello, J.C.; Guo, G.; et al. Concurrent alterations in TERT, KDM6A, and the BRCA pathway in bladder cancer. Clin. Cancer Res. 2014, 20, 4935-4948. [CrossRef] [PubMed] 
168. Ntziachristos, P.; Tsirigos, A.; Welstead, G.G.; Trimarchi, T.; Bakogianni, S.; Xu, L.; Loizou, E.; Holmfeldt, L.; Strikoudis, A.; King, B.; et al. Contrasting roles of histone 3 lysine 27 demethylases in acute lymphoblastic leukaemia. Nature 2014, 514, 513-517. [CrossRef] [PubMed]

169. Albert, M.; Helin, K. Histone methyltransferases in cancer. Semin. Cell. Dev. Biol. 2010, 21, $209-220$. [CrossRef] [PubMed]

170. Baugé, C.; Bazille, C.; Girard, N.; Lhuissier, E.; Boumediene, K. Histone methylases as novel drug targets: Developing inhibitors of EZH2. Future Med. Chem. 2014, 6, 1943-1965. [CrossRef] [PubMed]

171. Tan, J.; Yang, X.; Zhuang, L.; Jiang, X.; Chen, W.; Lee, P.L.; Karuturi, R.K.M.; Tan, P.B.O.; Liu, E.T.; Yu, Q. Pharmacologic disruption of Polycomb-repressive complex 2-mediated gene repression selectively induces apoptosis in cancer cells. Genes Dev. 2007, 21, 1050-1063. [CrossRef] [PubMed]

172. Miranda, T.B.; Cortez, C.C.; Yoo, C.B.; Liang, G.; Abe, M.; Kelly, T.K.; Marquez, V.E.; Jones, P.A. DZNep is a global histone methylation inhibitor that reactivates developmental genes not silenced by DNA methylation. Mol. Cancer Ther. 2009, 8, 1579-1588. [CrossRef] [PubMed]

173. Xie, Z.; Bi, C.; Cheong, L.L.; Liu, S.C.; Huang, G.; Zhou, J.; Yu, Q.; Chen, C.-S.; Chng, W.J. Determinants of sensitivity to DZNep induced apoptosis in multiple myeloma cells. PLoS ONE 2011, 6, e21583. [CrossRef] [PubMed]

174. Jiang, X.; Lim, C.Z.H.; Li, Z.; Lee, P.L.; Yatim, S.M.J.M.; Guan, P.; Li, J.; Zhou, J.; Pan, J.; Chng, W.-J.; et al. Functional characterization of D9, a novel deazaneplanocin A (DZNep) analog, in targeting acute myeloid leukemia (AML). PLoS ONE 2015, 10, e0122983. [CrossRef] [PubMed]

175. Knutson, S.K.; Wigle, T.J.; Warholic, N.M.; Sneeringer, C.J.; Allain, C.J.; Klaus, C.R.; Sacks, J.D.; Raimondi, A.; Majer, C.R.; Song, J.; et al. A selective inhibitor of EZH2 blocks H3K27 methylation and kills mutant lymphoma cells. Nat. Chem. Biol. 2012, 8, 890-896. [CrossRef] [PubMed]

176. Knutson, S.K.; Kawano, S.; Minoshima, Y.; Warholic, N.M.; Huang, K.C.; Xiao, Y.; Kadowaki, T.; Uesugi, M.; Kuznetsov, G.; Kumar, N.; et al. Selective inhibition of EZH2 by EPZ-6438 leads to potent antitumor activity in EZH2-mutant non-Hodgkin lymphoma. Mol. Cancer Ther. 2014, 13, 842-854. [CrossRef] [PubMed]

177. Campbell, J.E.; Kuntz, K.W.; Knutson, S.K.; Warholic, N.M.; Keilhack, H.; Wigle, T.J.; Raimondi, A.; Klaus, C.R.; Rioux, N.; Yokoi, A.; et al. EPZ011989, a potent, orally-available EZH2 inhibitor with robust in vivo activity. ACS Med. Chem. Lett. 2015, 6, 491-495. [CrossRef] [PubMed]

178. Qi, W.; Chan, H.; Teng, L.; Li, L.; Chuai, S.; Zhang, R.; Zeng, J.; Li, M.; Fan, H.; Lin, Y.; et al. Selective inhibition of Ezh2 by a small molecule inhibitor blocks tumor cells proliferation. Proc. Natl. Acad. Sci. USA 2012, 109, 21360-21365. [CrossRef] [PubMed]

179. McCabe, M.T.; Ott, H.M.; Ganji, G.; Korenchuk, S.; Thompson, C.; van Aller, G.S.; Liu, Y.; Graves, A.P.; Iii, A.D.P.; Diaz, E.; et al. EZH2 inhibition as a therapeutic strategy for lymphoma with EZH2-activating mutations. Nature 2012, 492, 108-112. [CrossRef] [PubMed]

180. Verma, S.K.; Tian, X.; LaFrance, L.V.; Duquenne, C.; Suarez, D.P.; Newlander, K.A.; Romeril, S.P.; Burgess, J.L.; Grant, S.W.; Brackley, J.A.; et al. Identification of potent, selective, cell-active inhibitors of the histone lysine methyltransferase EZH2. ACS Med. Chem. Lett. 2012, 3, 1091-1096. [CrossRef] [PubMed]

181. Amatangelo, M.D.; Garipov, A.; Li, H.; Conejo-Garcia, J.R.; Speicher, D.W.; Zhang, R. Three-dimensional culture sensitizes epithelial ovarian cancer cells to EZH2 methyltransferase inhibition. Cell Cycle 2013, 12, 2113-2119. [CrossRef] [PubMed]

182. Xu, B.; On, D.M.; Ma, A.; Parton, T.; Konze, K.D.; Pattenden, S.G.; Allison, D.F.; Cai, L.; Rockowitz, S.; Liu, S.; et al. Selective inhibition of EZH2 and EZH1 enzymatic activity by a small molecule suppresses MLL-rearranged leukemia. Blood 2015, 125, 346-358. [CrossRef] [PubMed]

183. Konze, K.D.; Ma, A.; Li, F.; Barsyte-Lovejoy, D.; Parton, T.; Macnevin, C.J.; Liu, F.; Gao, C.; Huang, X.-P.; Kuznetsova, E.; et al. An orally bioavailable chemical probe of the Lysine Methyltransferases EZH2 and EZH1. ACS Chem. Biol. 2013, 8, 1324-1334. [CrossRef] [PubMed]

184. Bradley, W.D.; Arora, S.; Busby, J.; Balasubramanian, S.; Gehling, V.S.; Nasveschuk, C.G.; Vaswani, R.G.; Yuan, C.-C.; Hatton, C.; Zhao, F.; et al. EZH2 inhibitor efficacy in non-Hodgkin's lymphoma does not require suppression of H3K27 monomethylation. Chem. Biol. 2014, 21, 1463-1475. [CrossRef] [PubMed]

185. Kim, W.; Bird, G.H.; Neff, T.; Guo, G.; Kerenyi, M.A.; Walensky, L.D.; Orkin, S.H. Targeted disruption of the EZH2-EED complex inhibits EZH2-dependent cancer. Nat. Chem. Biol. 2013, 9, 643-650. [CrossRef] [PubMed] 
186. Tang, S.; Huang, H.; Wu, H.; Tsai, Y.; Chuang, M. Pharmacologic down-regulation of EZH2 suppresses bladder cancer in vitro and in vivo. Oncotarget 2014, 5, 10342-10355. [CrossRef] [PubMed]

187. Wang, Y.; Xiang, W.; Wang, M.; Huang, T.; Xiao, X.; Wang, L.; Tao, D.; Dong, L.; Zeng, F.; Jiang, G. Methyl jasmonate sensitizes human bladder cancer cells to gambogic acid-induced apoptosis through down-regulation of EZH2 expression by miR-101. Br. J. Pharmacol. 2014, 171, 618-635. [CrossRef] [PubMed]

188. Copeland, R.A.; Solomon, M.E.; Richon, V.M. Protein methyltransferases as a target class for drug discovery. Nat. Rev. Drug Discov. 2009, 8, 724-732. [CrossRef] [PubMed]

189. Helin, K.; Dhanak, D. Chromatin proteins and modifications as drug targets. Nature 2013, 502, 480-488. [CrossRef] [PubMed]

190. Choudhury, S.R.; Balasubramanian, S.; Chew, Y.C.; Han, B.; Marquez, V.E.; Eckert, R.L. (-)-Epigallocatechin-3-gallate and DZNep reduce polycomb protein level via a proteasome-dependent mechanism in skin cancer cells. Carcinogenesis 2011, 32, 1525-1532. [CrossRef] [PubMed]

191. Kikuchi, J.; Takashina, T.; Kinoshita, I.; Kikuchi, E.; Shimizu, Y.; Sakakibara-Konishi, J.; Oizumi, S.; Marquez, V.E.; Nishimura, M.; Dosaka-Akita, H. Epigenetic therapy with 3-deazaneplanocin A, an inhibitor of the histone methyltransferase EZH2, inhibits growth of non-small cell lung cancer cells. Lung Cancer 2012, 78, 138-143. [CrossRef] [PubMed]

192. Hibino, S.; Saito, Y.; Muramatsu, T.; Otani, A.; Kasai, Y.; Kimura, M.; Saito, H. Inhibitors of enhancer of zeste homolog 2 (EZH2) activate tumor-suppressor microRNAs in human cancer cells. Oncogenesis 2014, 3, e104. [CrossRef] [PubMed]

193. Cheng, L.L.; Itahana, Y.; Lei, Z.D.; Chia, N.-Y.; Wu, Y.; Yu, Y.; Zhang, S.L.; Thike, A.A.; Pandey, A.; Rozen, S.; et al. TP53 genomic status regulates sensitivity of gastric cancer cells to the histone methylation inhibitor 3-deazaneplanocin A (DZNep). Clin. Cancer Res. 2012, 18, 4201-4212. [CrossRef] [PubMed]

194. Braun, F.K.; Mathur, R.; Sehgal, L.; Wilkie-Grantham, R.; Chandra, J.; Berkova, Z.; Samaniego, F. Inhibition of methyltransferases accelerates degradation of cFLIP and sensitizes B-cell lymphoma cells to TRAIL-induced apoptosis. PLoS ONE 2015, 10, e0117994. [CrossRef] [PubMed]

195. Kondo, Y. Targeting histone methyltransferase EZH2 as cancer treatment. J. Biochem. 2014, 156, $249-257$. [CrossRef] [PubMed]

196. Garapaty-Rao, S.; Nasveschuk, C.; Gagnon, A.; Chan, E.Y.; Sandy, P.; Busby, J.; Balasubramanian, S.; Campbell, R.; Zhao, F.; Bergeron, L.; et al. Identification of EZH2 and EZH1 small molecule inhibitors with selective impact on diffuse large B cell lymphoma cell growth. Chem. Biol. 2013, 20, 1329-1339. [CrossRef] [PubMed]

197. Balasubramanian, V.; Iyer, P.; Arora, S.; Troyer, P.; Normant, E. Abstract 1697: CPI-169, a novel and potent EZH2 inhibitor, synergizes with CHOP in vivo and achieves complete regression in lymphoma xenograft models. Cancer Res. 2014, 74, 1697-1697. [CrossRef]

198. Kung, P.-P.; Huang, B.; Zehnder, L.; Tatlock, J.; Bingham, P.; Krivacic, C.; Gajiwala, K.; Diehl, W.; Yu, X.; Maegley, K.A. SAH derived potent and selective EZH2 inhibitors. Bioorg. Med. Chem. Lett. 2015, 25, 1532-1537. [CrossRef] [PubMed]

199. Ma, R.; Wei, Y.; Huang, X.; Fu, R.; Luo, X.; Zhu, X.; Lei, W.; Fang, J.; Li, H.; Wen, W. Inhibition of GSK $3 \beta$ activity is associated with excessive EZH2 expression and enhanced tumour invasion in nasopharyngeal carcinoma. PLoS ONE 2013, 8, e68614. [CrossRef] [PubMed]

200. Jing, X.; Ueki, N.; Cheng, J.; Imanishi, H.; Hada, T. Induction of apoptosis in hepatocellular carcinoma cell lines by emodin. Jpn. J. Cancer Res. 2002, 93, 874-882. [CrossRef] [PubMed]

201. Cha, T.-L.; Chuang, M.-J.; Tang, S.-H.; Wu, S.-T.; Sun, K.-H.; Chen, T.-T.; Sun, G.-H.; Chang, S.-Y.; Yu, C.-P.; Ho, J.-Y.; et al. Emodin modulates epigenetic modifications and suppresses bladder carcinoma cell growth. Mol. Carcinog. 2015, 54, 167-177. [CrossRef] [PubMed]

202. Hu, S.; Yu, L.; Li, Z.; Shen, Y.; Wang, J.; Cai, J.; Xiao, L.; Wang, Z. Overexpression of EZH2 contributes to acquired cisplatin resistance in ovarian cancer cells in vitro and in vivo. Cancer Biol. Ther. 2010, 10, 788-795. [CrossRef] [PubMed]

203. Li, T.; Cai, J.; Ding, H.; Xu, L.; Yang, Q.; Wang, Z. EZH2 participates in malignant biological behavior of epithelial ovarian cancer through regulating the expression of BRCA1. Cancer Biol. Ther. 2014, 15, 271-278. [CrossRef] [PubMed] 
204. Adelaiye-Ogala, R.M.; Chintala, S.; Shen, L.; Orillion, A.; Ciamporcero, E.; Elbanna, M.; Miles, K.M.; Gillard, B.; Buck, M.; Pili, R. Abstract 3508: Inhibition of EZH2 overcomes resistance to sunitinib in clear cell renal cell carcinoma models. Cancer Res. 2015, 75, 3508. [CrossRef]

205. Lv, Y.; Yuan, C.; Xiao, X.; Wang, X.; Ji, X.; Yu, H.; Wu, Z.; Zhang, J. The expression and significance of the enhancer of zeste homolog 2 in lung adenocarcinoma. Oncol. Rep. 2012, 28, 147-154. [PubMed]

206. Reijm, E.A.; Timmermans, A.M.; Look, M.P.; Meijer-van Gelder, M.E.; Stobbe, C.K.; van Deurzen, C.H.M.; Martens, J.W.M.; Sleijfer, S.; Foekens, J.A.; Berns, P.M.J.J.; et al. High protein expression of EZH2 is related to unfavorable outcome to tamoxifen in metastatic breast cancer. Ann. Oncol. 2014, 25, 2185-2190. [CrossRef] [PubMed]

207. Fan, T.-Y.; Wang, H.; Xiang, P.; Liu, Y.-W.; Li, H.-Z.; Lei, B.-X.; Yu, M.; Qi, S.-T. Inhibition of EZH2 reverses chemotherapeutic drug TMZ chemosensitivity in glioblastoma. Int. J. Clin. Exp. Pathol. 2014, 7, 6662-6670. [PubMed]

208. De Vries, N.A.; Hulsman, D.; Akhtar, W.; de Jong, J.; Miles, D.C.; Blom, M.; van Tellingen, O.; Jonkers, J.; van Lohuizen, M. Prolonged EZH2 depletion in glioblastoma causes a robust switch in cell fate resulting in tumor progression. Cell. Rep. 2015, 10, 383-397. [CrossRef] [PubMed]

(C) 2015 by the authors; licensee MDPI, Basel, Switzerland. This article is an open access article distributed under the terms and conditions of the Creative Commons by Attribution (CC-BY) license (http://creativecommons.org/licenses/by/4.0/). 